NBER WORKING PAPER SERIES

EMPLOYER SIZE AND

THE WAGE STRUCTURE IN

U.S. MANUFACTURING

Steven J. Davis

John Haltiwanger

Working Paper 5393

\author{
NATIONAL BUREAU OF ECONOMIC RESEARCH \\ 1050 Massachusetts Avenue \\ Cambridge, MA 02138 \\ December 1995
}

Both authors are also research associates at the Center for Economic Studies, Bureau of the Census. In preparing the LRD data for this study, we have greatly benefited from the assistance of Bob Bechtold, Tim Dunne, James Monahan, Robert McGuckin and other Census Bureau employees at the Center for Economic Studies. We also thank Kevin Murphy for helpful discussions on CPS data. Laura Power and Catharine Buffington provided excellent research assistance. We gratefully acknowledge research support provided by the National Science Foundation, a Joint Statistical Agreement between the Census Bureau and the University of Maryland, and the Graduate School of Business at the University of Chicago. This paper is part of NBER's research program in Labor Studies. Any opinions expressed are those of the authors and not those of the National Bureau of Economic Research.

(C) 1995 by Steven J. Davis and John Haltiwanger. All rights reserved. Short sections of text, not to exceed two paragraphs, may be quoted without explicit permission provided that full credit, including $\odot$ notice, is given to the source. 
NBER Working Paper 5393

December 1995

\title{
EMPLOYER SIZE AND \\ THE WAGE STRUCTURE IN \\ U.S. MANUFACTURING
}

\begin{abstract}
We study how the hourly wage structure varies with establishment size and how wage dispersion breaks down into between-plant and within-plant components. Our study combines household and establishment data for the U.S. manufacturing sector in 1982.

1. Wage dispersion falls sharply with establishment size for nonproduction workers and mildly for production workers.

2. Size-class differences in wage dispersion often mask even sharper differences in the dispersion of wages generated by observable worker characteristics and in the "skill prices" on those characteristics.
\end{abstract}

3. In terms of dispersion in predicted log wages,

- worker heterogeneity tends to rise with establishment size;

- production workers are much more homogenous in the union sector, but only at plants with 1,000 or more workers.

4. Unobserved factors generate sharply greater wage dispersion at smaller establishments.

5. The variance in mean wages across establishments accounts for $59 \%$ of total variance. Within-plant wage variance among production workers accounts for a mere $2 \%$.

6. Mean wage differences by size of establishment account for about one-fourth of the total between-plant variance of wages.

7. Between-plant wage dispersion falls sharply with establishment size, entirely accounting for the negative relationship of establishment size to overall wage dispersion.

Guided by these and other empirical findings, we assess several hypotheses about the determination of the wage structure.

Steven J. Davis

Graduate School of Business

The University of Chicago

1101 East 58th Street

Chicago, IL 60637

and NBER
John Haltiwanger

Department of Economics

University of Maryland

College Park, MD 20742

and NBER 
November 1995

\section{Introduction}

Larger employers pay substantially higher wages. This strong empirical regularity holds up across studies that span several decades, many countries and regions, and a broad range of industries and occupations. ${ }^{1}$ Evidence for the U.S. manufacturing sector points to sharply rising size-wage differentials over time.

A few facts from our previous work on the subject (Davis and Haltiwanger, 1991) convey the magnitude of size-wage differentials, their growth over time, and their relationship to the general increase in U.S. wage inequality that has occurred since the 1970s. Among U.S. manufacturing production workers, the wage differential between plants with more than 5,000 employees and plants with 20 to 49 employees rose from $\$ 3.40$ an hour (1982 dollars) in 1967 to $\$ 6.31$ an hour in 1986 . These size-wage differentials, and the increase over time, are huge relative to the overall mean production worker wage of $\$ 8.18$ an hour in 1967 and $\$ 9.18$ an hour in 1986. Furthermore, the rise in the size-wage premium accounts for a significant fraction of the growth in overall wage inequality. Between 1976 and 1985 , rising size-wage differentials account for $40 \%$ of the increase in between-plant wage dispersion among U.S. manufacturing plants, and the between-plant component in turn accounts for $48 \%$ of the overall growth in wage variance among manufacturing workers.

As we show in this paper, the dispersion of wages also exhibits a pronounced relationship to employer size. In particular, overall wage dispersion falls sharply with establishment size for both production and nonproduction workers in the U.S. manufacturing

${ }^{1}$ Early studies include Moore (1911), Rehn (1954) and Lester (1967). Brown and Medoff (1989) and Brown et al (1990) review much of the evidence on the size-wage relationship. Chapter 5 in Brown et al shows that larger employers also offer more attractive fringe benefits. 
sector. This empirical relationship entirely reflects a smaller between-plant component of wage dispersion among larger establishments. Within-plant wage dispersion actually rises with establishment size.

The factors underlying the empirical regularities involving employer size and wages are not well understood. A careful study by Brown and Medoff (1989) explores several hypotheses about the source of mean wage differentials among employers of different sizes: (i) larger employers hire higher quality workers; (ii) larger employers offer inferior working conditions; (iii) larger employers are more likely to be unionized or pay higher wages to avoid unionization; (iv) larger employers have greater rents to share with workers; (v) larger employers pay higher efficiency wages in response to monitoring problems; and (vi) larger employers have relatively low applicant-to-vacancy ratios. The only hypothesis to receive empirical support in their study is worker quality differences among size classes, which account for roughly one-half of observed size-wage differentials. Thus, Brown and Medoff's findings indicate that nearly half of observed mean wage differentials by employer size remains unexplained.

In this paper, we investigate how the distribution of manufacturing workers' hourly wages differs among establishment size classes. We use person-level information on hourly earnings, demographic characteristics, union coverage status and employer size to quantify how (i) differences in observable worker and job characteristics, (ii) differences in the wages associated with observable characteristics and (iii) differences in unobserved factors contribute to differences among employer size classes in the structure of wages. We also combine person-level data with establishment-level data to decompose total wage dispersion into between-plant and within-plant components. We carry out this decomposition by employer size class, an exercise that enables us to infer how between-plant and within-plant wage dispersion varies by size of establishment. 
We anticipate that a better understanding of the connection between employer size and the structure of the wage distribution will shed additional light on the connection between employer size and mean wages, the focus of most previous research on the size-wage relationship. In addition, several interesting and largely unexplored hypotheses involve the connection between employer size and the dispersion of wages among workers, both between plants and within plants: (i) unions compress wages within plants, and larger plants are more likely to be unionized or to mimic union wage policies as a union avoidance tactic; (ii) large employers rely more heavily on ability-sensitive methods of pay for managerial employees, (iii) large employers are more likely to use a standardized technology requiring homogeneous workers; (iv) large employers carry out a greater variety of tasks and accordingly have a greater diversity of workers; (v) larger employers rely more heavily on standard rate pay policies, leading to greater compression of wages (conditional on observable worker characteristics); and (vi) the heterogeneity in average workforce quality is greater among small employers than among large employers. We provide direct and indirect evidence related to these and other hypotheses about the connection between employer size and the wage structure.

Our study combines several sources of data. We obtain person-level wages and other data from the Employee Benefits Supplement to the May 1983 Current Population Survey (CPS), which is matched to the March 1983 Annual Demographic File. The Benefits Supplement includes information on employer size and union status, and the Annual Demographic File includes information on hourly earnings in 1982. We draw upon the 1982 Census of Manufactures to obtain data on individual manufacturing establishments.

Since several of the wage structure hypotheses relate most directly to within-plant dispersion, we restrict our attention to the manufacturing sector. For this sector, we can combine CPS data with Census of Manufactures data in the Longitudinal Research Database (LRD) to decompose total wage dispersion into between-plant and within-plant components, using the methodology developed in Davis and Haltiwanger (1991). Our 
previous work on this decomposition devoted considerable attention and effort to adjustments for possible biases induced by the exclusion of administrative establishments from the LRD sampling frame. In this study, we augment the LRD to incorporate administrative and auxiliary establishments in the manufacturing sector, thereby yielding a data set with observations on the universe of U.S. manufacturing establishments in 1982. The data on administrative and auxiliary establishments are drawn from the Census Bureau's Standard Statistical Establishment List (SSEL). Henceforth, references to the LRD in this paper should be understood to reflect an augmented version of the LRD that includes administrative and auxiliary establishments.

We note that several other recent studies stress the role of establishment size in establishment-level wage, employment and productivity behavior. Dunne, Roberts and Samuelson (1989) show that plant failure rates are sharply decreasing in plant size. Davis and Haltiwanger (1992) and Davis, Haltiwanger and Schuh (1996) present evidence that the dispersion of establishment-level growth rates is inversely related to plant size. Baily, Hulten and Campbell (1992) show that plant-level productivity is an increasing function of plant size. Dunne and Schmitz (1991) find that larger plants are more likely to adopt advanced technologies, and that this difference in technology adoption behavior accounts for part of the size-wage differential. Troske (1994) shows that capital intensity differences play an important role in accounting for mean wage differences among different size employers. Taken together, these and many other studies make clear that employer size is a key correlate of wage, employment and productivity behavior.

\section{Basic Patterns in the Size-Wage Relationship}

Figures 1 and 2 depict mean hourly wages in 1982 by establishment size class for production and nonproduction workers in the manufacturing sector. The figures consider 100 size classes, each representing $1 \%$ of manufacturing employment. We construct these figures from the augmented LRD, which contains observations on all U.S. manufacturing 
establishments in 1982. Thus, the data set contains approximately 300,000 manufacturing establishments employing about 18.5 million workers. This large number of establishmentlevel observations enables us to draw a much sharper picture of the relationship between size and mean wages than previous research.

Some useful refinements result from the sharper picture, and two points, in particular, emerge clearly. First, mean size-wage differentials are large for both production and nonproduction workers. For production workers, the mean wage differential between plants in the 10th and 90th size classes is $\$ 5.05$ per hour, which equals about $62 \%$ of the overall mean production worker wage. Second, the size-wage relationship is sharply nonlinear (in size class percentiles), and it differs between production and nonproduction workers. For production workers, wages rise systematically with size, although the slope is much steeper in the upper half of the size distribution. For nonproduction workers, wages rise steeply with size in the first 10 size classes, fall slightly between the 15th and 50th size class, and then rise sharply between the 50th and 100th size classes. ${ }^{2}$

Figures 3 and 4 depict the mean and coefficient of variation of hourly wages by establishment size class for manufacturing production and nonproduction workers. We construct these figures from the 1982 earnings data in the 1983 March-May matched CPS files. These two figures display a striking contrast between the wage mean and wage dispersion relationships to establishment size. Although mean wages rise sharply with size, wage dispersion falls sharply, especially for nonproduction workers. Moving from plants with 1-24 employ${ }^{2}$ For nonproduction workers, the LRD contains observations on employment and annual earnings but not hours worked. We use the CPS to impute hours worked for nonproduction workers based on industry, ownership type and size class. Given the limitations of the data available for our imputation procedure, it is possible that the sharp rise in mean wages for nonproduction workers over the first ten size classes reflects a heavier use of part-time workers by the smallest establishments. 
ees to plants with $1000+$ employees, the coefficient of variation for hourly wages falls from $44 \%$ to $38 \%$ for production workers and from $66 \%$ to $49 \%$ for nonproduction workers.

Figures 1-4 show quite clearly that mean wages and wage dispersion exhibit pronounced variation by size of employer. In subsequent sections, we endeavor to improve our understanding of these strong empirical patterns. Because certain hypotheses regarding the role of employer size are apt to be most relevant in the upper tail of the wage distribution (e.g., tournament effects) or the lower tail of the wage distribution (e.g., minimum wage laws), much of our analysis considers particular segments of the wage distribution. Before returning to the data, we discuss several factors that possibly underlie the pronounced covariation between employer size and the wage structure. Section VII collects our main empirical findings and assesses several hypotheses articulated in the next section.

\section{Employer Size and the Wage Structure: Theoretical Factors}

Previous research points to three broad categories of factors generating wage structure differences among employers of different sizes: technological heterogeneity, institutional and noncompetitive factors, and incentive based pay mechanisms. We discuss these factors in this section. Because it is often unclear whether particular influences on the wage structure involve firm or establishment effects, our discussion blurs the distinction between them.

\section{Technological Heterogeneity}

Technological heterogeneity among industries and among plants within industries arises for many reasons. For example, if the choice of production technique entails sunk costs, then vintage and locational differences in initial conditions generate persistent heterogeneity in production techniques among operating plants. Lambson (1991) shows that even when firms face identical initial conditions and have identical information sets, uncertainty about future conditions induces heterogeneity in the choice of production technique. 
Alternatively, production complementarities among heterogeneous workers can induce heterogeneity in production technique. In this vein, Lucas (1978) and Oi (1983) develop models in which firm heterogeneity arises from heterogeneity in entrepreneurial ability. Preferences over working conditions can also play a role, as when some workers prefer a lower-paying job in a cleaner, safer work environment. See Rosen (1986). Another class of models stresses the role of learning processes in determining the degree of heterogeneity among firms or plants. Thus, Jovanovic (1982) develops a model of firm heterogeneity that stresses the selection effects associated with passive learning about initial conditions. Ericson and Pakes (1990) develop a theory of firm heterogeneity induced by active learning about idiosyncratic investment outcomes.

Various sources of technological heterogeneity can induce sorting by worker ability among plants, which in turn leads to differences in the wage structure across plants. The central issue for our purpose is whether the sorting mechanisms generated by technological heterogeneity lead to systematic differences in the wage structure among employers of different sizes. Hamermesh (1990) suggests that larger plants use higher-quality workers more intensively because of greater capital intensity at larger plants and complementarities between physical capital and worker skill. In Lucas's (1978) model, larger plants employ more skilled workers because they are complementary to the more talented managers who run them. Kremer (1993) emphasizes that greater task complexity implies greater skill complementarities among workers. Consequently, if larger plants operate technologies characterized by greater task complexity, they will also select a more skilled workforce. Oi (1983) and Garen (1985) argue that large plants employ higher-quality workers to reduce monitoring costs per unit of labor services. Oi also argues that firm-specific human capital accumulation occurs primarily at large firms and plants. If workers with more overall human capital have a comparative advantage in accumulating firm-specific skills, then Oi's thesis implies another technological source of sorting by worker ability among 
employers of varying sizes. All of these sorting mechanisms generate a positive, skill-based relationship between employer size and mean wages.

Do these sorting mechanisms have implications for the relationship between employer size and other aspects of the wage structure? A general point is that sorting mechanisms that differentially affect the skill mix by employer size lead to differences in dispersion by size class. Oi argues that larger employers hire workers with greater mean skill levels and more homogeneous skill levels. In Oi's view, the relationship between employer size and worker homogeneity follows because larger employers rely more intensively on standardized production technologies that call for homogeneous labor. This view implies that withinplant wage dispersion falls with plant size. Kremer's analysis suggests a different reason why within-plant wage dispersion may fall with plant size: if larger plants are more likely to adopt technologies with greater skill complementarities, then workers at larger plants will have high average skills and low dispersion of skills. Yet another argument is put forth by Garen (1985), who argues that within-plant dispersion falls with plant size, because higher screening and monitoring costs imply less sensitivity of wages to ability at larger plants.

Technological heterogeneity can also plausibly work to increase wage dispersion among workers at larger plants. Larger employers may engage in a greater variety of tasks within each plant, because they are more diversified horizontally and vertically. If greater task variety requires greater skill heterogeneity among workers, then within-plant wage dispersion is likely to rise with employer size.

Simple models of the link between employer size and task variety also carry implications for between-plant wage inequality. Consider the class of models that satisfies the following three assumptions. One, large production units - e.g., a large establishment are just random groupings of small production units. Two, each small production unit contains a homogeneous workforce. Three, the mapping from worker characteristics to wage outcomes is the same across production units. It then follows that the within-plant 
variance wages rises with size, the between-plant variance declines with size, and their sum is unrelated to size.

Another role for technological heterogeneity in the relationship between employer size and the wage structure involves the life-cycle dynamics of firms and plants. Smaller and younger plants exhibit much greater dispersion in employment growth rates than larger and older plants (e.g., Davis, Haltiwanger and Schuh, 1996). Greater growth rate dispersion among small plants may reflect greater technological diversity. Consider a scenario related to Lambson's analysis. Suppose that young, small plants select technologies from a wide range of alternatives and that, over time, plants with technologies less suited to the realized state of the world are selected out. The successful plants that become older and larger will then be drawn from a narrower range of the distribution of technologies. If different technologies generate different patterns of sorting by worker skill, as seems likely, then greater technological diversity among small plants would lead to greater diversity in average workforce quality. Consequently, between-plant wage dispersion falls with plant size (and age).

Institutional and Noncompetitive Factors

We turn now to noncompetitive and institutional factors that possibly influence the wage structure in different ways, or to a different degree, among employers of different sizes. These noncompetitive factors receive considerable attention in previous research on both union wage effects and inter-industry wage differentials (e.g., Katz and Summers (1989)).

Many explanations for inter-industry wage differentials are based on the idea that the nature of the employer-employee relationship differs systematically across industries. This same idea can be applied to argue that the nature of the employer-employee relationship differs systematically across plants of different sizes. For example, monitoring technologies can vary across plants of different sizes. If monitoring is imperfect and more difficult at 
larger plants, and if workers cannot effectively buy high-rent jobs through explicit bonds or implicit bonding mechanisms, then employer size-wage differentials can emerge following standard efficiency wage arguments (e.g., Bulow and Summers, 1986). ${ }^{3}$

Wage dispersion between and within plants can also arise from differences in rents to be shared, whatever their source, or differences among workers in their capacity to extract rents. Aside from the factors stressed by efficiency wage theories, rents can arise when individual employers have product market power, when certain employers have technological or other cost advantages, or when barriers to entry in the product market are coupled with barriers to entry in the labor market. If wages are partly determined by rent sharing considerations, and if larger plants have greater rents to share, then employer size wage differentials result. Conceivably, only certain workers within firms have the bargaining power to extract rents from firms, so that - conditional on workers' skill characteristics wage dispersion also varies with employer size.

Unions seek to influence the between-plant and within-plant structure of wages, and unionism often figures prominently in explanations for noncompetitive wage differentials (Lewis 1986, Freeman and Medoff 1984). The well-documented union wage gap is associated with wage differentials between plants and between worker types. The fact that larger plants exhibit a significantly higher incidence of unionization suggests the possibility that unionism plays an important role in the relationship between employer size and wages (e.g., Podgursky, 1986). The available evidence also indicates that larger employers are more likely to be targets of unionization drives (Voos, 1983, and Brown et al, 1990), which suggests that larger non-union employers may choose to more closely mimic union pay patterns to avoid unionization.

\footnotetext{
${ }^{3}$ Our discussion of monitoring effects under the heading of "technological heterogeneity" involves sorting among heterogeneous workers. Efficiency wage theories of how monitoring relates to the wage structure do not involve worker heterogeneity in any fundamental way.
} 
Freeman $(1980,1982)$ argues that unions compress wage differentials among workers by promoting standard rate compensation policies. These standard rate policies typically involve uniform compensation schedules across establishments (for similar workers) and impersonal rates or ranges of rates in a given occupational class within establishments. By inducing wage compression among union members, both between and within plants, standard rate policies are thought to promote solidarity among union members (Farber and Saks, 1980). In addition, Addison and Hirsch (1986, p. 156) claim that "Because the number of job and pay classifications that can reasonably be defined within a collective bargaining contract typically is less than the number employers would make based on individual evaluations in a nonunion setting, unionism will tend to lessen the dispersion in wages." Regardless of the reason, the evidence strongly suggests that unions succeed in compressing important aspects of the wage structure relative to outcomes in the absence of unionization.

These remarks about union wage structure effects and the relationship between employer size and unionization lead to two related hypotheses: (i) both between-plant wage dispersion and within-plant wage dispersion fall with employer size; (ii) the strength of the relationship between wage compression and employer size depends on the strength of the relationship between employer size and unionization (or threat of unionization).

Looking beyond the role of unions, the incidence of standard rate policies may be linked to employer size for other reasons. If larger employers are more likely to institutionalize compensation policies that tie wages to easily observable worker characteristics, then wage dispersion will tend to decline with employer size after conditioning on these characteristics. This idea has a long history in descriptive analyses of the wage structure; see, for example, Reynolds and Taft (1956, p. 170).

Incentive Based Pay Mechanisms 
The use of incentive based pay mechanisms that reward high effort and productivity have been used to help explain observed pay structures internal to the firm. For example, Lazear and Rosen (1981) argue that tournament mechanisms raise output and productivity and help explain earnings profiles that rise with experience. To the extent that these mechanisms are more prevalent at larger employers (or perhaps because the size of the tournament is larger at larger employers), they suggest that wage dispersion rises with employer size. Further, since these incentive mechanisms are likely to be more important for managerial workers, this argument applies most naturally to the upper portion of the earnings distribution for nonproduction workers.

A related set of factors may push in the opposite direction. While incentive based mechanisms that reward high productivity and effort would seem to be output enhancing, they need not be if individual workers can affect the productivity of coworkers. As Lazear (1989) makes clear, in environments where workers have the ability to affect each other's output, wage compression may be optimal. Under this hypothesis, standard rate pay policies are justified for efficiency reasons as opposed to institutional reasons. For the present purpose, the question is whether the ability to affect the productivity of a coworker is systematically related to employer size. Plausible stories could be given for this effect to be go either way.

\section{Summary of Hypotheses}

As emphasized by Brown and Medoff (1989), there are many potential explanations for a rising mean wage with employer size. Our discussion makes clear that there are also many potential explanations for a systematic relationship between employer size and other aspects of the wage structure. Hypotheses that predict a positive relationship between employer size and within-plant dispersion include (i) larger employers carry out a greater variety of tasks and therefore have a more diverse workforce; and (ii) larger employers are

more likely to use incentive-based pay mechanisms. Hypotheses that predict a negative 
relationship between employer size and within-plant dispersion include (i) larger employers are more likely to use technologies that require homogeneous workers; (ii) unions compress wage differentials among workers, and unionization is more prevalent among larger employers; (iii) larger employers are more likely to adopt standard rate policies that link wages to easily observable worker characteristics; and (iv) workers at larger employers find it easier to undermine the productivity of coworkers. Hypotheses that predict a negative relationship between employer size and the between-plant dispersion of wages include (i) smaller employers are more technologically diverse than large employers; and (ii) unions compress the between-plant dispersion of wages, and unionization is more prevalent among larger employers. The empirical investigation below sheds light on the foregoing hypotheses by investigating how several aspects of the wage structure vary with employer size.

\section{The Data}

Employer size class information is available in the May 1983 CPS file. This information permits an analysis of the relationship between wages, employer size and a host of worker characteristics. Size class information is also available in the 1979 and 1988 May CPS files, but we focus on the 1983 file for two reasons. First, changes in size class definitions over time limit consistent analysis by size class over time. In particular, establishment size class definitions in 1987 for manufacturing are much more limited (the top size class is 250+ workers). Second, the focus in this paper is on the cross sectional relationship between employer size and the distribution of wages. In future work, we plan to examine time series changes in the size-wage structure.

Both previous week and previous year earnings figures are available in the CPS files. We focus on earnings last year for two reasons. First, the incidence of topcoding is much higher in the previous week earnings measures. Top-code incidence in the last year figures is 
small and, for production workers, very small. ${ }^{4}$ Second, the last year hourly wage measure in the CPS is conceptually consistent with the hourly wage measure available in the LRD. In both cases, hourly wages are computed as the ratio of annual earnings to annual hours worked. This consistency facilitates the decomposition of total wage variance into betweenplant and within-plant components. We carry out this decomposition by matching the last year information from the 1983 CPS file with the 1982 Census of Manufactures data in the LRD (as noted above, augmented with the SSEL).

In matching a worker based survey (CPS) and an establishment based survey (LRD), several issues arise concerning compatibility and consistency. Table 1 reports basic statistics on the size distribution of hours, employment and payroll in the CPS, the augmented LRD, and County Business Patterns (CBP). Broadly speaking, the three datasets show the same basic patterns. The LRD and the CBP tabulations match very closely. The tabulations from the CPS show the same general patterns, but with a higher share of hours, employment and payroll in the smallest size class (less than 25) and lower shares in the three largest size classes. Part of this discrepancy reflects slightly different size class definitions in the two smallest CBP size categories. ${ }^{5}$

Because the LRD provides the hours-weighted mean wage at individual plants, the between-plant/within-plant decomposition must be done in levels rather than log wages. Since the bulk of studies using the CPS focus on the standard deviation of log wages, it is useful to know the relationship between the standard deviation of log wages and the

\footnotetext{
${ }^{4}$ We adjust the last year earnings figures for topcoding in the same way as Juhn, Murphy and Pierce (1993) and Katz and Murphy (1992).

${ }^{5}$ Other potential reasons for a discrepancy include (i) misreporting of size class by workers in the CPS; (ii) CPS tabulations that do not use CPS sample weights; (iii) sample selection bias associated with missing size class data in the CPS; and (iv) a systematic correlation between the industrial misclassification of workers in the CPS and their establishment size class.
} 
coefficient of variation of wages. Table 2 presents alternative wage dispersion measures by worker type and plant size for 1982 . This table shows that the log standard deviation and coefficient of variation of wages in the CPS exhibit similar patterns of variation across size classes with one exception: for production workers, the coefficient of variation falls between the 500-999 and 1000+ size classes, whereas the log standard deviation rises. Table 2 also reports the number of observations in each size class category for the two worker types.

The LRD does not contain a measure of hours worked by nonproduction workers. Rather, for nonproduction workers, the LRD reports only the annual wage bill and the number of workers during the mid-March payroll period. We use the following algorithm to impute nonproduction worker hours at the establishment level in the LRD. First, compute mean hours per nonproduction worker for each two-digit industry/size class/ownership type cell, where ownership type refers to the distinction between single-plant and multiplant firms. Second, apply the CPS-based cell means for hours per nonproduction worker to the establishment-level LRD measure of nonproduction worker employment.

\section{Differences in Worker Characteristics and Mean Wages Among Size Classes}

\section{Worker Characteristics by Establishment Size Class}

We begin our investigation by considering how worker characteristics vary by establishment size. As reported in Table 3, workers at large establishments have higher mean levels of schooling, experience and tenure. They are more likely to be male, married, covered by a union wage contract, engaged in a nonproduction activity, work for a multi-unit firm, and work in an SMSA. These patterns support the view that larger establishments employ more skilled workers, possibly because of sorting induced by technological heterogeneity. The positive relationship between establishment size and union contract coverage is consistent with the view that unions play an important role in the relationship between employer size and the wage structure. 
Some notable differences between production and nonproduction workers stand out in Table 3. First, no more than $6 \%$ of production workers in any size class hold a college degree. In contrast approximately one-third of nonproduction workers at establishments with fewer than 500 employees have a college degree, and this fraction rises to $48 \%$ at establishments with 1000 or more employees. Second, the positive relationship between establishment size and mean labor market experience holds for production workers only. Third, and in contrast to the experience pattern, mean tenure rises sharply with establishment size for both production and nonproduction workers. Finally, union contract coverage is much higher among production workers, and union coverage rates rise very sharply with establishment size among production workers.

\section{Accounting for Mean Wage Differentials}

To facilitate comparison with other research, we briefly consider the ability of the observable characteristics in our data set to account for mean log wage differences among size classes. Results of this investigation appear in Figure 5, which depicts actual and fitted relationships between employer size and mean log wages. The fitted relationships are generated from regressions that pool observations across size classes but treat production workers and nonproduction workers separately. The "human capital" regression specification contains quadratics in years of education, experience and tenure, plus a dummy for sex. The "all controls" specification adds two-digit industry effects and dummies for race, multi-unit firms, and union contract coverage.

Figure 5 shows that a significant fraction of the mean log wage differentials among size classes can be accounted for by the controls. As Brown and Medoff (1989) found, much of the explanatory power comes from the human capital variables. However, in our data the human capital controls account for important mean wage differences only in comparisons that involve the larger size classes. The slope of the relationship between mean wages and 
establishment size is quite flat over the first three or four size classes, depending on worker type.

\section{Differences in the Wage Distribution Among Size Classes}

\section{Accounting for Differences in the Wage Distribution}

To characterize the contribution of observables and unobservables to differences in the wage distribution among size classes, we use the full distribution accounting methodology of Juhn, Murphy and Pierce (1993). Using the JMP methodology, we estimate the effects of differences among size classes in (i) the distribution of observable worker and other characteristics, (ii) the wage effects associated with observable characteristics, and (iii) the distribution of regression residuals.

To understand the methodology, consider the regression equation

$$
W_{i s}=X_{i s} \beta_{s}+u_{i s}
$$

where $W_{i s}$ is the $\log$ wage for individual $i$ in size class $s, X_{i s}$ is a vector of observable characteristics, and $u_{i s}$ represents the part of the wage unaccounted for by observables. Following JMP, we think of this residual as reflecting the individual's percentile in the residual distribution, $\omega_{i s}$, and the distribution function of the residuals, $F_{s}\left(\cdot \mid X_{i s}\right)$. Here, we allow for the possibility that the residual distribution function varies with certain observable worker characteristics. It follows from the preceding definitions that

$$
u_{i s}=F_{s}^{-1}\left(\omega_{i s} \mid X_{i s}\right)
$$

where $F_{s}^{-1}\left(\cdot \mid X_{i s}\right)$ is the inverse cumulative residual distribution for workers with characteristics $X_{i s}$ in $s$.

We can now decompose variation in the worker-wage distribution within each size class into three parts: variation in the distribution of observable characteristics (the $X$ 's), variation in the wage effects (the $\beta$ 's) associated with a given set of observable characteristics, 
and variation in the residual distributions. Defining $\bar{\beta}$ as the average of the estimated wage effects in the size class regressions and $\bar{F}\left(\cdot \mid X_{i s}\right)$ as the average cumulative distribution, ${ }^{6}$ we can represent this decomposition by

$$
W_{i s}=X_{i s} \bar{\beta}+\bar{F}^{-1}\left(\omega_{i s} \mid X_{i s}\right)+X_{i s}\left(\beta_{s}-\bar{\beta}\right)+\left(F_{s}^{-1}\left(\omega_{i s} \mid X_{i s}\right)-\bar{F}^{-1}\left(\omega_{i s} \mid X_{i s}\right)\right)
$$

The first two terms in this decomposition capture the contribution of variation across size classes in the distribution of observable characteristics for fixed wage effects. The third term captures the contribution of differing wage effects. The final term captures the contribution of differences in the distribution of regression residuals that are unexplained by differences in the $\beta$ 's and differences in the distribution of the $X$ 's. We can use the decomposition in (1) to isolate the contribution of these three types of variation to the total variation in the wage structure among size classes.

To isolate the contribution of differences in the distribution of observable characteristics, consider

$$
W_{i s}^{1}=X_{i s} \bar{\beta}+\bar{F}^{-1}\left(\omega_{i s} \mid X_{i s}\right)
$$

Differences among size classes in the distribution over the $W_{i s}^{1}$ represent estimates of how variation in the observable characteristics among size classes influences differences in the wage structure. As (2) makes clear, the estimated contribution of the observable characteristics to differences in the wage structure depends on both the regressor list and on the list of conditioning variables for the residual distribution function.

To generate the marginal contribution of differences in wage effects to differences in the wage structure across size classes, consider

$$
W_{i s}^{2}=X_{i s} \beta_{s}+\bar{F}^{-1}\left(\omega_{i s} \mid X_{i s}\right)
$$

${ }^{6}$ In practice, we compute these averages from a pooled regression equation with size-class specific intercept terms. 
The distribution over the $W_{i s}^{2}$ reflects both wage effects and observable characteristics. Now think of calculating the distribution over the $W_{i s}^{2}$ for each size class, as well as the distribution over the $W_{i s}^{1}$ for each size class. For each of these sets of distributions, we can calculate various summary statistics. Comparing the 90-10 percentile range, for example, as generated by distributions over the $W_{i s}^{1}$ and the $W_{i s}^{2}$, yields an estimate of the marginal contribution of differing wage effects to differences in the 90-10 range across size classes. Similar remarks apply to other measures of inequality.

Likewise, we can generate the marginal contribution of differences in the unobservables to differences in the wage structure by considering

$$
W_{i s}^{3}=X_{i s} \beta_{s}+F^{-1}\left(\omega_{i s} \mid X_{i s}\right)=X_{i s} \beta_{s}+u_{i s}=W_{i s}
$$

Hence, comparing the distribution over the $W_{i s}$ to the distribution over the $W_{i s}^{2}$ yields the marginal contribution of differences in the unobservables to differences in the wage structure.

\section{Full Distribution Accounting Results}

Figures 6-11 summarize the results of the full distribution accounting exercises. Panels A display the gap between two selected percentiles of the observed log wage distribution for each size class. Panels B-D display the JMP decomposition of the wage gap and differences in the wage gap among size classes. To facilitate direct visual comparisons, all plots are scaled in the same way. The "human capital" and "all controls" specifications contain the same regressors as before, except that we add size class fixed effects. For both specifications, we permit the distribution function of the residuals to vary across four education categories: fewer than twelve years of schooling, exactly twelve years of schooling, some college, and four or more years of college.

Figure 6 shows that overall wage dispersion among production workers, as measured by the 90-10 differential in log wages, falls modestly with plant size. Panels B-D of Figure 6 reveal that this modest decline hides striking differences by plant size in workers' 
wage generating characteristics and in the wages or "skill prices" received by workers. In particular, Panel B indicates that differences in observable worker characteristics generate a strong positive relationship between wage dispersion and employer size. If production workers' wages were the same function of observable characteristics regardless of plant size, then the 90-10 wage differential would be 24 log points greater among workers at plants with 500-999 employees than among workers at plants with 1-24 employees. Almost all of this increase in the $\mathbf{9 0 - 1 0}$ wage differential is accounted for by the human capital characteristics. In contrast, Panel $A$ shows that the $90-10$ wage gap is actually $7 \log$ points smaller among workers at plants with 500-999 employees.

It is helpful to restate the basic point of Figure 6, Panel B in a somewhat different manner: Using the Panel B 90-10 log wage differential as an index of heterogeneity in worker skills, workers are most heterogenous in the 500-999 size class, and they are least heterogenous in the 1-24 size class. Workers in the largest plants are no more heterogenous than workers in plants with 25-99 employees and much less heterogeneous than workers in plants with 500-999 employees. Thus, while these data show sharp differences in the degree of skill heterogeneity across size categories, the relationship to size is not monotonic.

Panel $\mathrm{C}$ of Figure 6 shows that the mapping between observable worker characteristics and wage outcomes also differs sharply by size class. Isolating the role of differences in "skill prices" among size classes, wage dispersion tends to fall with employer size. Again, the relationship is not monotonic. Workers at plants with 500-999 employees exhibit substantially greater compression of skill differentials than workers at either larger or smaller plants.

Panel D of Figure 6 reveals that unobservable factors make a considerably greater marginal contribution to wage dispersion at smaller plants. The $90-10$ wage differential is 18 log points greater at small plants than at large plants for the "all controls" specification and $16 \log$ points greater for the "human capital" specification. This pattern supports the 
hypothesis that larger employers rely more heavily on standard rate policies that tie wages for production workers to easily observed characteristics.

Figure 7 indicates that some of the same basic patterns re-emerge for nonproduction workers. First, to the extent that observables matter, the basic human capital variables sex, education, experience and tenure - provide most of the explanatory power for size-class differences in the role of observable characteristics. Second, the 500-999 size class again exhibits the greatest heterogeneity in terms of workers' wage-generating characteristics. Unlike for production workers, however, wage effects are not relatively compressed among nonproduction workers in the 500-999 size class.

The most striking pattern in Figure 7 is the strong negative relationship between establishment size and the marginal contribution of unobserved factors to the $90-10 \mathrm{log}$ wage differential. According to Panel D, and using the "all controls" specification, the role of unobserved factors is $28 \mathrm{log}$ point greater among workers at the smallest plants than among workers at the largest plants. Looking ahead, Panels D in Figures 8-11 reveal that unobserved factors induce greater wage compression among workers at larger plants in both halves of the wage distribution and for both worker types. Evidently, plant size covaries strongly with important aspects of workers or wage-generating mechanisms that are unobserved in the fairly standard list of variables in our regression specification.

Figure 8 presents the decomposition of the 90-50 differential for production workers. Dispersion in the upper half of the distribution is similar across the three smallest size classes but decreases sharply between the 100-499 size class and the $1000+$ size class. Observable characteristics and the wage effects associated with these characteristics are associated with modest differences in the 90-50 wage differential across size classes. According to panel B, the upper half of the worker quality distribution shows the least heterogeneity among workers at the largest plants and the greatest heterogeneity among workers at plants with 100-499 employees. Panel $\mathrm{C}$ indicates that the greatest skill price compression in the upper half of the wage distribution occurs among workers in the 500-999 size class. 
Figure 9 presents the decomposition of the 90-50 differential for nonproduction workers. In the upper half of the wage distribution for nonproduction workers, one might expect to see incentive-based pay mechanisms operating to generate greater wage dispersion and greater dispersion in skill prices at larger plants. The evidence is not consistent with this expectation. Instead, wage dispersion in the upper half of the distribution falls sharply with establishment size. Furthermore, Panels $\mathrm{C}$ and $\mathrm{D}$ reveal no tendency for the marginal contribution of skill prices or unobserved factors to rise with establishment size. Indeed, Panel D shows a rather remarkable pattern of smaller marginal contributions of unobserved factors at larger establishments. ${ }^{7}$

Figure 10 presents the decomposition of the 50-10 differential for production workers. In contrast to the 90-50 differential, the 50-10 differential rises modestly, although not monotonically, with plant size. Observable characteristics generate greater 50-10 log wage differentials at larger establishments. The 500-999 size class again stands out as having the greatest amount of worker heterogeneity and the greatest compression of skill prices. Unobservable factors contribute to moderately greater compression of the 50-10 log wage differential for production workers at larger plants.

Figure 11 presents the decomposition of the 50-10 differential for nonproduction workers. The 50-10 differential first falls, then rises, then falls again by plant size. Worker characteristics, particularly human capital characteristics, generate a positive relationship of the 50-10 log wage differential to establishment size. The marginal contribution of skill price differences to the 50-10 differentials among size classes roughly tracks the erratic pattern of the actual 50-10 differential. As in each of the other figures, Panel D indicates that unobservable factors contribute to greater wage compression at larger establishments.

${ }^{7}$ We have performed JMP decompositions on the 90-75 wage gap for nonproduction workers with results similar to the reported results for the 90-50 gap. Of course, our results do not rule out the possibility that incentive effects generate important wage spreading in the upper decile of the wage distribution. 


\section{The Role of Unions}

Figures 6-11 identify several patterns in the relationship between establishment size and the structure of wages. Section II points to unions as a potentially important determinant of wage structure differences among size classes. To investigate the role of unions in these differences, we considered four channels through which unions potentially influence the size-wage structure.

First, unions may compress the wage structure by influencing workforce composition. To investigate this possibility, we computed the 90-10 log wage differential implied by observable wage-generating characteristics for each size class/union status combination. We used the $W_{1}$ values for production workers that underlie Panel $\mathrm{B}$ in Figure 6. The results show little difference in workforce heterogeneity between the union and nonunion sectors for the four smallest size classes but a much more homogeneous union workforce at the largest establishments. For establishments with $1000+$ workers, observable characteristics generate a 90-10 wage differential of 113 log points in the nonunion sector but only $87 \log$ points in the union sector. Furthermore, the $90-10$ differential generated by the observable characteristics rises monotonically with establishment size in the nonunion sector. These results imply that the drop off in production worker heterogeneity at the largest establishments (Panel B in Figure 6) entirely reflects the greater homogeneity among workers covered by union contracts. ${ }^{8}$

Second, if unions alter the returns to education, experience and tenure, differences among establishment size classes in the extent of union contract coverage generate differ-

\footnotetext{
${ }^{8}$ For the $500-999$ size class in the union sector, observable characteristics generate a $90-10$ wage differential of 115 log points, modestly larger than the corresponding value in the nonunion sector, and about the same as the value reported in the text for the union sector with $1000+$ employees. Thus, our data suggest that unions are strongly associated with greater workforce homogeneity, but only at the largest establishments.
} 
ences in the wage structure. ${ }^{9}$ To investigate this possibility, we interacted union status with the human capital variables in our regression specifications. After estimating the interacted specifications, we plotted new versions of the "observable characteristics" curve in Panel B of Figures 6-11. The shape of the Panel B curves changed little as a consequence of introducing the interaction terms, and so we concluded that unions account for negligible wage structure differences among establishment size classes through this channel.

Third, unions might alter the returns to skill in different ways, or to a different degree, across size classes. We investigated this matter by examining both the interacted-unionstatus regressions discussed above and other unreported regressions. We found evidence that the union wage premium among production workers is smaller for men than women, especially at small establishments. In other respects, we found no systematic differences among size classes in the impact of union status on the returns to skill. We concluded that unions do not account for important wage structure differences among establishment size classes through this channel.

Fourth, the evidence discussed in section II indicates that unions significantly compress the wage distribution conditional on observable worker characteristics. Thus, one might suspect that greater union coverage at larger establishments for production workers (Table 3) underlies the negative relationship between establishment size and the marginal contribution of unobservable factors to the $90-10$ wage differential (Panel D in Figure 6). ${ }^{10}$

\footnotetext{
${ }^{9}$ Several previous studies find evidence that unions alter skill prices, but the review of this literature by Hirsch and Addison (1986, section 6.6) points to no broad empirical regularities.

${ }^{10}$ As a separate but related point, the impact of union coverage on the contribution of unobservable factors to wage dispersion might differ by establishment size class, as suggested by results in Kahn and Curme (1987). If collective bargaining agreements promote the type of standard rate policies that large employers tend to implement anyway, then union effects on residual wage dispersion will be more pronounced for smaller establishments.
} 
To investigate the role of unions in this respect, we calculated the marginal contribution of unobserved factors to the 90-10 log wage differential separately for the union and nonunion sectors. We used the $W_{2}$ and $W_{3}$ values for production workers that underlie Panel D in Figure 6. Both the union and nonunion sectors show the greatest contribution of unobserved factors to the $90-10 \log$ wage differential in the 1-24 size class, but no other clear results emerged from this exercise.

In addition, we calculated the 90-10 differential of log wage residuals separately by size class and union status. Somewhat to our surprise, we found little evidence of greater residual wage compression in the union sector. ${ }^{11}$ We concluded that unions do not account for the important wage structure differences among size classes depicted by the negative relationship between establishment size and the marginal contribution of unobservable factors to the 90-10 wage differential.

\section{Between-Plant and Within-Plant Components of Wage Dispersion}

We now combine information from the household and establishment surveys to decompose the variance of hourly manufacturing wages into between-plant and within-plant components. The decomposition quantifies the contribution of each component to the dis-

$\overline{{ }^{11} \text { Work by Freeman (1980) }}$ and others led us to anticipate substantially greater residual wage compression in the union sector. Instead, for both raw and residual log wages among production workers, we found only slightly greater dispersion in the nonunion sector. (For nonproduction workers, our data show substantially greater compression in the union sector, but as Table 3 indicates the union sector is relatively unimportant among manufacturing nonproduction workers.) The reasons for the discrepancy between our results and Freeman (1980) are not clear to us, but we note that Freeman defined the union sector in terms of membership, whereas we use contract coverage. Our data do not contain information on union membership. 
persion of manufacturing wages in each of the establishment size classes available in the CPS.

\section{Decomposition Methodology}

The variance of hourly wages across hours worked in the manufacturing sector can be written as

$$
\begin{aligned}
V & =\alpha V^{p}+(1-\alpha) V^{n}+\alpha(1-\alpha)\left(\bar{W}^{p}-\bar{W}^{n}\right)^{2}, \\
& =\alpha\left(V_{B P}^{p}+V_{W P}^{p}\right)+(1-\alpha)\left(V_{B P}^{n}+V_{W P}^{n}\right)+\alpha(1-\alpha)\left(\bar{W}^{p}-\bar{W}^{n}\right)^{2},
\end{aligned}
$$

where $\alpha$ denotes production workers' share of hours worked, $V^{p}$ denotes the variance of wages across hours worked by production workers, $\widehat{W}^{p}$ denotes the hours-weighted mean wage for production workers, $V_{B P}^{p}$ denotes the hours-weighted variance of mean production worker wages across plants, $V_{W P}^{p}$ denotes the hours-weighted mean of the production worker wage variances within plants, and the remaining terms denote analogous quantities for nonproduction workers. The first line of (5) expresses the total variance of hourly wages as the hours-weighted sum of within-worker-type and between-worker-type components. The second line further decomposes the within-worker-type components into between-plant and within-plant components. We apply this decomposition to total manufacturing and to each size class available in the March-May CPS files.

The between-plant and within-plant variance terms in (5) cannot be isolated from standard household surveys like the CPS, although the CPS does permit estimation of their sums, $V^{p}$ and $V^{n}$, by size class. To isolate the separate components of these sums, we first calculate $V_{B P}$ by size class directly from plant-level wage data in the LRD. We then estimate the within-plant wage variance as a residual in a standard variance decomposition,

$$
\hat{V}_{W P}=V\left(W_{h}^{C}\right)-V_{B P}
$$

where $V\left(W_{h}^{C}\right)$ is the hours-weighted variance of measured wages in the CPS. 
To estimate the components of (5), we proceed as follows. From the individual-level wage observations in the CPS March files, we calculate $\alpha, \bar{W}^{p}, \bar{W}^{n}, V^{p}$ and $V^{n}$ for each size class. From the plant-level wage observations in the LRD, we calculate $V_{B P}$ for each size class. Using (6), we then estimate $V_{W P}$ for each size class. All calculations on individual and plant observations are carried out on an hours-weighted basis.

Since Figures 1 and 2 indicate that mean wages vary systematically by plant size, and given the broad size classes available in the CPS, the between-plant wage dispersion in each size class partly reflects size wage differentials. It follows that differences across size classes in the between-plant dispersion of wages are partly an artifact of the CPS size-class boundaries. To address this matter, we further decompose between-plant wage dispersion into a component that reflects size-wage differentials within the size class and a residual component. This residual component, denoted by $V_{B P S}$, measures the amount of between-plant wage dispersion due to all factors other than size-wage effects. To estimate $V_{B P S}$ we use the 100 size classes underlying Figures 1 and 2.

\section{Measurement Error Issues}

Several measurement error issues arise in connection with our decomposition methodology. In Davis and Haltiwanger (1991), we focused on the measurement error that arises from misreported wages in the CPS. We described conditions on the measurement error structure for wage observations such that equation (6) produces unbiased estimates of the within-plant wage variance. We argued that existing evidence on the structure of wage measurement error in household surveys, although quite limited, is consistent with these conditions. We also remark that our estimates of differences in the within-plant variance across size classes are not biased by wage measurement error, provided only that the measurement error structure is stable across size classes.

Second, as we noted earlier, it is necessary to impute hours worked per nonproduction worker in the LRD. For production workers, the LRD reports annual hours worked and 
the annual wage bill for each plant. ${ }^{12}$ For nonproduction workers, the LRD reports only the annual wage bill and the number of employees in the mid-March payroll period during the year. As explained above, we use the CPS to impute hours worked per nonproduction worker based on industry, ownership type and size class of plant. Because this method delivers imprecise estimates, we further adjusted the LRD plant-level means and variances for nonproduction workers, so that the ratio of the LRD to CPS mean for nonproduction workers equals the corresponding ratio for production workers. We carried out this adjustment by size class.

Finally, there are two additional and related sources of measurement error in our decomposition. One source involves workers who misreport their employer's size class. Table 1 reveals some discrepancy in the distribution of hours worked by plant size class, especially in the 1-24 size class. Another source of measurement error involves missing observations on employer size class in the CPS. We see no reason to believe that the decomposition results reported below are driven by measurement errors of these types, but we have not attempted to quantify or adjust for their presence.

\section{Decomposition Results}

Table 4 reports the decomposition given by equation (5). Results for the "all plants" column essentially reproduce 1982 results from Davis and Haltiwanger (1991). A detailed comparison of the results in Table 4 and those in Davis and Haltiwanger (1991) reveals that the inclusion of the administrative and auxiliary plants has only a minor impact on

${ }^{12}$ In the LRD, the annual wage bill includes salaries, wages, commissions, dismissal pay, paid bonuses, vacation and sick leave pay, and the cash equivalent of compensation paid in kind. The annual wage bill does not include supplementary wage costs such as the employer's social security contributions, other legally required expenditures, or payments for voluntary employer programs such as health insurance. 
the results. ${ }^{13} 59 \%$ of the total variance in wages is accounted for by the variance in mean wages across plants. The mean wage gap between production and nonproduction workers accounts for $8 \%$ of total variance. The remaining $33 \%$ is accounted for by the within-plant variance of wages for the two worker types. The within-plant variance of wages is much greater among nonproduction workers than among production workers.

The "all plants" column in Table 4 also indicates that size-wage differentials account for $26 \%$ of between-plant wage variance among production workers and $23 \%$ among nonproduction workers. This figure is calculated by considering the between-plant variance of wages with and without the adjustment for mean size effects. For example, using the information in lines 4 and 5, we calculate the fraction of between-plant production worker wage variance accounted for by size effects as $1-(3.17)^{2} /(3.68)^{2}=.26$.

For production workers, the within-plant and between-plant standard deviations exhibit U-shaped patterns across size classes, as does the total standard deviation. The contribution of within-plant variance for production workers to total dispersion is very small for all size classes, ranging from $1 \%$ to $9 \%$ and bearing no simple relationship to plant size. As seen by a comparison of the $V_{B P}$ and $V_{B P S}$ entries, the contribution of size-wage effects to between-plant dispersion within size classes is trivial except in the $1000+$ class. This result indicates that most of the influence of size-wage differentials on between-plant wage dispersion is captured by the size class definitions available in the 1983 CPS.

For nonproduction workers, the within-plant standard deviation of wages rises sharply with establishment size, whereas the between-plant standard deviation of wages falls sharply with size. The contribution of the within-plant variance among nonproduction ${ }^{13}$ An important reason for this minor impact is that our earlier work contains adjustments for missing administrative and auxiliary establishments. The good news from the current results is that the adjustments apparently were effective. 
workers rises from 22 percent of total variance at establishments with 1-24 employees to 46 per cent at establishments with $1,000+$ employees.

Given pronounced mean wage differences, comparisons of wage dispersion among size classes are perhaps most appropriately carried out in terms of the coefficient of variation. Figure 12 depicts the within-plant and between-plant coefficients of variation by size class. In this figure, the coefficient of variation for between-plant dispersion is calculated using $V_{B P S}$ for reasons explained above.

As seen earlier in Figures 3 and 4, Figure 12 shows total dispersion falling by size class. For nonproduction workers, the between-plant coefficient of variation falls sharply with size class, amounting to $55 \%$ in the $1-24$ size class but only $27 \%$ in the $1000+$ size class. For production workers, the between-plant coefficient of variation also falls with size class but not as sharply. This wage dispersion measure equals $43 \%$ in the 1-24 size class and $33 \%$ in the $1000+$ size class.

The within-plant coefficient of variation for nonproduction workers rises modestly and nonmonotonically with establishment size. It peaks in the $100-499$ size class at $44 \%$. The within-plant coefficient of variation for production workers is quite low in all size classes and exhibits an erratic relationship to size. As for nonproduction workers, within-plant wage dispersion for production workers peaks in the 100-499 size class, reaching a value of $23 \%$. For both the 1-24 and 500-999 size class, the within-plant coefficient of variation for production workers is only $8 \%$.

The tendency for within-plant wage dispersion to rise with establishment size for nonproduction workers is supportive of two hypotheses: larger plants rely more heavily on incentive based pay mechanisms, and there is a greater diversity of workers within larger plants. Because we found no evidence in section $V$ that incentive-based pay mechanisms operate with greater force among workers in larger establishments, we infer that withinplant wage dispersion rises with size because larger employers have more heterogeneous workforces. 
The most striking aspect of Figure 12 is the finding that the smaller amounts of wage dispersion seen among workers at large plants entirely reflects smaller dispersion of mean wages between plants. This finding supports the hypothesis that smaller employers are more technologically diverse than large employers.

\section{Collecting the Facts and Assessing the Hypotheses}

This study investigates how the wage structure varies with establishment size and how wage dispersion breaks down into between-plant and within-plant components. We collect our main findings, all of which pertain to the U.S. manufacturing sector in 1982, and we then briefly assess several hypotheses about the determinants of the size-wage structure.

1. Mean wages are sharply higher at larger establishments. For production workers, the mean wage at the 90th percentile of the employment-weighted size distribution exceeds the mean wage at the 10 th percentile by $62 \%$ of the overall mean production worker wage. For nonproduction workers, the corresponding size-wage gap equals $21 \%$ of the mean wage.

2. Mean wages vary modestly with size over the bottom half of the employment-weighted distribution, but they rise sharply over the upper half of the distribution.

3. Wage dispersion falls sharply with establishment size for nonproduction workers and mildly for production workers. The coefficient of wage variation among nonproduction (production) workers ranges from $66 \%$ (44\%) at establishments with 1-24 employees to $49 \%(38 \%)$ at establishments with 1,000 or more employees.

4. Size-class differences in wage dispersion often mask even sharper differences in the dispersion of wages generated by observable worker characteristics and in the "skill prices" on those characteristics. Constraining the wage function to be the same across size classes, the predicted $90-10$ differential is $24 \log$ points greater among production workers at plants with 500-999 employees than at plants with 1-24 employees. (The wage regression underlying this statement includes standard "human capital" variables 
plus controls for industry, race, union status, establishment size and multi-plant firms.) In contrast, the 90-10 log wage gap is actually 7 log points smaller among workers at the larger plants.

5. In terms of 90-10 differentials generated by predictions from a log wage regression, worker heterogeneity tends to rise with establishment size. Among production workers in the nonunion sector, this index of heterogeneity rises monotonically with size.

6. Union contract coverage is strongly associated with greater homogeneity among production workers at the largest plants (1,000 or more employees). At these plants, the 90-10 log wage differential generated by observable characteristics is $113 \log$ points in the nonunion sector but only 87 log points in the union sector. We find no notable union effects on this index of worker heterogeneity at smaller establishments.

7. Skill prices on observable worker characteristics differ, sometime sharply, across establishment size classes, but they exhibit no systematic relationship to size.

8. The most prevalent and pronounced aspect of wage structure variation across establishment size classes involves the role of unobserved factors - i.e., unmeasured differences in workers' wage-generating characteristics and unobserved differences in the mapping from these characteristics to wage outcomes. For nonproduction (production) workers, the marginal contribution of unobservables to the $90-10$ wage differential is 28 (18) $\log$ points greater at the smallest establishments than at the largest establishments. The same pattern holds separately with respect to the 90-50 and 50-10 differentials.

9. Aside from point 6 above, we find no evidence that union contract coverage plays an important role in the relationship between establishment size and the dispersion of wages. As a related point, we find little evidence that union contract coverage compresses the residual wage distribution among production workers in any size class. Union contract coverage compresses residual wage dispersion among nonproduction workers, but this effect has small consequences because of low union coverage rates. 
10. The variance in mean wages across establishments accounts for $59 \%$ of the overall variance in hourly manufacturing wages. Within-plant wage variance among nonproduction workers accounts for $31 \%$ of the total variance and among production workers a mere $2 \%$. The remaining $8 \%$ of hourly wage variance is accounted for by the mean wage gap between production and nonproduction workers.

11. Mean wage differences by size of establishment account for about one-fourth of the total between-plant variance of wages for both production and nonproduction workers.

12. The negative relationship of establishment size to wage dispersion (point 3 above) entirely reflects the behavior of the between-plant component of wage dispersion. The between-plant coefficient of wage variation for nonproduction (production) workers falls from $55 \%(43 \%)$ at establishments with $1-24$ employees to $27 \%(33 \%)$ at establishments with 1,000 or more employees. In contrast, the within-plant coefficient of wage variation tends to rise with establishment size.

How do the hypotheses articulated in section II fare in the face of these findings. While several hypotheses find support in particular aspects of the results, no single hypothesis explains all, or even many, of the prominent patterns in the relationship between employer size and the wage structure.

Most of the evidence runs counter to the hypothesis that larger establishments rely on technologies that require relatively homogeneous workers. Indeed, based on the wage differentials predicted from observable worker characteristics, worker heterogeneity tends to rise with establishment size. The main exception involves production workers at very large establishments who are covered by a union wage contract.

Aside from unionized production workers at very large establishments, the heterogeneity results are consistent with the hypothesis that the typical large establishment selects a relatively heterogeneous workforce because it carries out a greater variety of tasks than the typical smaller establishment. The heterogeneity results are also consistent with the hypothesis of greater between-plant differences among larger establishments in the type 
of task performed and the type of worker hired. One cannot discriminate between these two interpretations based on the person-level data (CPS) alone, but the decomposition of wage variance into between-plant and within-plant components strongly favors the first interpretation. Hence, we conclude that larger establishments in the U.S. manufacturing sector are characterized by relatively high levels of worker heterogeneity within plants.

Our results provide no support for the hypothesis that wage dispersion rises with employer size, because (i) incentive-based pay mechanisms are more prevalent or more important at larger establishments, and (ii) such mechanisms lead to greater wage dispersion conditional on observable characteristics. The sharp negative relationships for nonproduction workers between size and both the actual 90-50 wage differential and the contribution of unobservables to this differential are especially damaging to this hypothesis. Unreported results for the 90-75 differentials show a similar pattern. Despite our negative evidence on this two-part hypothesis, none of our results speak to the degree of wage spreading in the upper decile of the distribution.

We find a sharp negative relationship between establishment size and the marginal contribution of unobserved factors to wage dispersion. Unobserved factors make a much greater contribution to wage dispersion among workers at smaller establishments, especially for nonproduction workers.

Previous research points to the lower incidence of unionization among small establishments as a likely explanation for the greater contribution of unobservables to wage dispersion at small establishments. That is, the wage-compressing effects of unions are more important for workers at larger establishments because union contract coverage is more prevalent. We find no evidence to support this explanation. In this respect, we emphasize that the relative contribution of unobservables to wage dispersion at small establishments is especially pronounced among nonproduction workers, for whom union coverage rates are low in all establishment size classes. Hence, we conclude that union wage effects do not 
underlie the sharp size class differences in the contribution of unobserved factors to wage dispersion.

Instead, we interpret the evidence as strongly supporting the view that larger employers are much more likely to implement and enforce standard rate pay policies, whereby compensation is closely tied to easily observed worker and job characteristics. This view has a long tradition in anecdotal treatments of wage-setting behavior, but we are unaware of much systematic evidence on the issue in previous work. Neither are we aware of fully articulated theories directed towards an explanation for why larger employers adhere more closely to standard rate compensation policies. Our evidence suggests that this topic merits greater attention.

One other aspect of our empirical results merits attention, although it does not involve the size-wage structure. Our evidence shows a remarkable degree of within-plant wage uniformity among manufacturing production workers. The within-plant coefficient of wage variation for production workers ranges from $23 \%$ at establishments with 100-499 employees to less than 9\% at those with 1-24 workers and 500-999 employees. These are raw measures of wage dispersion with no controls for worker characteristics or job characteristics other than establishment size. Under the maintained assumption that wages equal marginal products, this degree of within-plant wage uniformity is consistent with considerable between-plant sorting by worker ability for reasons stressed in Kremer's (1993) O-ring theory of production, but it is also consistent with production functions that offer little scope for more able workers to produce more than the average worker. Lazear's (1989) theory of pay equality offers an interpretation of high within-plant wage uniformity that does not necessarily involve wages equal to marginal products. 
Table 1 Percentage Distribution of Hours, Employment, and Payroll by Establishment Size, U.S. Manufacturing Sector, 1982

\begin{tabular}{lllllll} 
& Data & \multicolumn{5}{c}{ Number of Employees } \\
& Source & $<25$ & $25-99$ & $100-499$ & $500-999$ & $1000+$ \\
Hours & CPS & 14.5 & 18.4 & 31.2 & 11.5 & 24.3 \\
Hours & LRD & 8.3 & 17.5 & 33.7 & 13.3 & 27.2 \\
Workers & CPS & 15.7 & 18.6 & 31.1 & 11.1 & 23.4 \\
Workers & CBP & 7.3 & 19.6 & 33.1 & 13.4 & 26.7 \\
Workers & LRD & 8.6 & 17.7 & 33.7 & 13.2 & 26.9 \\
Payroll & CPS & 12.9 & 16.8 & 28.6 & 11.9 & 29.9 \\
Payroll & CBP & 5.9 & 16.5 & 29.6 & 13.6 & 34.5 \\
Payroll & LRD & 6.9 & 15.1 & 30.1 & 13.4 & 34.5
\end{tabular}

Notes:

(1) Data sources are as follows: CPS denotes the 1983 May Current Populaton Survey (Employee Benefits Supplement); CBP denotes 1982 County Business Patterns; and LRD denotes the 1982 Longitudinal Research Datafile, augmented to include administrative and auxilliary establishments.

(2) CPS figures are based on the size of the establishment corresponding to the main job held in the week prior to the survey week. Reported CPS size-class figures are percentages of employees with non-missing values for size class.

(3) The CBP data represent employee counts tabulated from the mid-March payrolls of all tax-paying manufacturing establishments, including administrative and auxilliary establishments.

(4) For CBP tabulations, the first two size-class intervals are 1-19 employees and 20-99 employees. 
Table 2 Alternative Wage Dispersion Measures by Worker Type and Plant Size, U.S. Manufacturing Sector, 1982

\section{Production Workers}

Establishment Size Class (Number of Employees)

Dispersion Measure

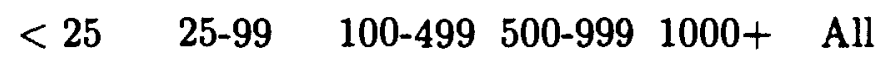

Coefficient of Variation

$\begin{array}{llllll}0.44 & 0.43 & 0.44 & 0.40 & 0.38 & 0.44\end{array}$

Coefficient of Variation

0.44

0.43

0.44

0.40

0.38

0.44

Standard Deviation of

0.41

0.41

0.42

0.39

0.41

0.43

Log Wage

Sample Size

This Table

Regression Analysis

$\begin{array}{lllll}268 & 299 & 466 & 185 & 469 \\ 213 & 268 & 426 & 180 & 445\end{array}$

\section{Nonproduction Workers}

Establishment Size Class (Number of Employees)

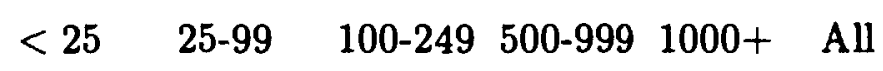

Dispersion Measure

Coefficient of Variation

$\begin{array}{llllll}0.66 & 0.60 & 0.58 & 0.51 & 0.49 & 0.57 \\ 0.56 & 0.50 & 0.51 & 0.49 & 0.45 & 0.51\end{array}$

Standard Deviation of

$$
0.56
$$

0.50

0.51

0.49

0.45

Workers

Log Wage

Sample Size

This Table

Regression Analysis

$\begin{array}{lllll}423 & 519 & 904 & 304 & 561 \\ 293 & 470 & 846 & 292 & 543\end{array}$

Note:

(1) Calculated from the matched March observations on hourly wages (annual earnings last year divided by hours worked last year) in the 1983 May CPS Employee Benefits Supplement.

(2) Missing values for certain regressors account for the smaller sample sizes in the regression analysis. 
Table 3 Worker and Establishment Characteristics by Establishment Size, U.S. Manufacturing Sector, Tabulated from the May 1983 CPS

\begin{tabular}{lllllll}
\multicolumn{5}{c}{ Establishment Size Class (Number of Employees) } \\
& $<25$ & $25-99$ & $100-499$ & $500-999$ & $1000+$ & All Workers \\
Mean Schooling & 12.3 & 12.0 & 12.1 & 12.4 & 13.1 & 12.2 \\
Prod. Workers & 11.2 & 11.0 & 11.2 & 11.3 & 11.9 & \\
Nonprod. Workers & 13.8 & 13.6 & 13.8 & 14.0 & 14.5 & \\
\% Coll. Ed. & 0.16 & 0.14 & 0.13 & 0.19 & 0.25 & 0.16 \\
Prod. Workers & 0.04 & 0.03 & 0.03 & 0.05 & 0.06 & \\
Nonprod. Workers & 0.34 & 0.32 & 0.32 & 0.40 & 0.48 & \\
Mean Experience & 19.2 & 20.6 & 21.1 & 21.5 & 21.8 & \\
Prod. Workers & 18.4 & 21.5 & 21.9 & 22.6 & 23.1 & \\
Nonprod. Workers & 20.3 & 19.1 & 19.6 & 19.8 & 20.2 & \\
Mean Tenure & 8.2 & 9.5 & 10.1 & 11.8 & 13.5 & 10.8 \\
Prod. Workers & 7.4 & 9.4 & 10.4 & 11.8 & 13.9 & \\
Nonprod. Workers & 9.3 & 9.7 & 9.5 & 11.7 & 13.0 & \\
\% Male & 0.76 & 0.72 & 0.64 & 0.65 & 0.65 & 0.70 \\
\% White & 0.93 & 0.92 & 0.90 & 0.88 & 0.91 & 0.90 \\
\% Black & 0.04 & 0.06 & 0.08 & 0.09 & 0.07 & 0.08 \\
\% Married & 0.73 & 0.74 & 0.76 & 0.77 & 0.79 & 0.75 \\
\% Union Coverage & 0.12 & 0.26 & 0.35 & 0.35 & 0.40 & 0.27 \\
Prod. Workers & 0.17 & 0.34 & 0.45 & 0.50 & 0.60 & \\
Nonprod. Workers & 0.06 & 0.12 & 0.16 & 0.12 & 0.16 & \\
\% Production Worker & 0.59 & 0.61 & 0.65 & 0.61 & 0.53 & 0.61 \\
\% Multi-Unit Firm & 0.39 & 0.58 & 0.76 & 0.90 & 0.93 & 0.72 \\
\% Single-Unit Firm & 0.60 & 0.38 & 0.21 & 0.09 & 0.06 & 0.27 \\
\% SMSA & 0.58 & 0.60 & 0.53 & 0.54 & 0.66 & 0.59 \\
Sa & & & & & &
\end{tabular}

Notes:

(1) All figures calculated on an hours-weighted basis.

(2) The "All Workers" column includes self-employed persons and persons who did not report establishment size.

(3) "Union Coverage" indicates the hours-weighted fraction of workers who report that they are covered by a union wage contract. 
Table 4 Between-Plant and Within-Plant Components of Hourly Wage Variance, U.S. Manufacturing Sector, by Establishment Size Class

\section{All Establishments, 1982}

Wage Figures in 1982 Dollars

\section{Component}

1. Total Variance of Hourly Wages, $V$

2. Standard Deviation of Hourly Wages

3. Standard Deviation of PW Hourly Wages w/i Plants

4. Standard Deviation of PW Hourly Wages between Plants

5. Standard Deviation of PW Hourly Wages between Plants Adjusted for Mean Size Effects

6. Standard Deviation of NPW Hourly Wages w/i Plants

7. St. Dev. of NPW Hourly Wages between Plants

8. St. Dev. of NPW

Hourly Wages between Plants Adjusted for Mean Size Effects

9. Mean NPW Wage

Minus Mean PW Wage

10. Production Worker Fraction of Hours Worked, $\alpha$

Establishment Size Class (Number of Employees) $\begin{array}{lllll}1-24 & 25-99 & 100-499 & 500-999 & 1000+\end{array}$

$\begin{array}{llllll}29.85 & 26.76 & 24.80 & 26.93 & 33.66 & 29.60\end{array}$

$\begin{array}{llllll}5.46 & 5.17 & 4.98 & 5.19 & 5.80 & 5.44\end{array}$

$\begin{array}{llllll}0.58 & 1.56 & 1.87 & 0.74 & 2.15 & 1.08\end{array}$

$\begin{array}{llllll}3.28 & 2.98 & 3.06 & 3.41 & 3.57 & 3.68\end{array}$

$\begin{array}{llllll}3.28 & 2.98 & 3.04 & 3.39 & 3.34 & 3.17\end{array}$

$\begin{array}{llllll}4.03 & 4.26 & 4.87 & 4.95 & 5.74 & 4.85\end{array}$

$\begin{array}{llllll}5.87 & 5.17 & 4.17 & 4.05 & 3.76 & 4.81\end{array}$

$\begin{array}{llllll}5.82 & 5.17 & 4.17 & 4.04 & 3.52 & 4.23\end{array}$

$\begin{array}{llllll}3.14 & 3.26 & 2.91 & 3.82 & 3.11 & 3.25\end{array}$

Fraction of Total Wage Variance Accounted for by the Term in:

Line 3, $\alpha V_{W P}^{p}$

$\begin{array}{llll}0.01 & 0.06 & 0.09 & 0.01\end{array}$

Line $4, \alpha V_{B P}^{p}$

0.21

0.20

0.24

0.26

0.07

0.02

Line 5, $\alpha V_{B P S}^{p}$

0.21

0.20

0.24

0.26

0.20

0.18

0.28

Line 6, $(1-\alpha) V_{W P}^{n}$

0.22

0.26

0.34

0.36

0.46

0.21

Line $7,(1-\alpha) V_{B P}^{n}$

0.48

0.38

0.25

0.24

0.20

0.31

Line $8,(1-\alpha) V_{B P S}^{n}$

0.47

0.38

0.25

0.24

0.17

0.30

Line $9, \alpha(1-\alpha)\left(W^{p, C P S}-W^{n, C P S}\right)^{2}$

0.08

0.09

0.08

0.13

0.07

0.23

Notes:

(1) The variance decomposition relies on data from the LRD and CPS and is based on equation (5) in the text. PW denotes production workers, and NPW denotes nonproduction workers.

(2) All figures are computed on an hours-weighted basis. 


\section{References}

Baily, Martin, Charles Hulten, and David Campbell (1992) "Productivity Dynamics in Manufacturing Plants," Microeconomic Brookings Papers on Economic Activity, 1992

Brown, Charles, James Hamilton and James Medoff (1990) Employers Large and Small, Cambridge, Massachusetts: Harvard University Press.

Brown, Charles and James Medoff (1989) "The Employer Size Wage Effect," Journal of Political Economy, 97, no. 5, 1027-1059.

Bulow, Jeremy I. and Lawrence H. Summers (1986) "A Theory of Dual Labor Markets with Application to Industrial Policy, Discrimination, and Keynesian Unemployment, Journal of Labor Economics, 4, no. 3, part 1 (July), 376-414.

Davis, Steven J. and John Haltiwanger (1991) "Wage Dispersion Between and Within U.S. Manufacturing Plants, 1963-86" Microeconomic Brookings Papers on Economic Activity, 1991.

Davis, Steven J. and John Haltiwanger (1992) "Gross Job Creation, Gross Job Destruction, and Employment Reallocation," Quarterly Journal of Economics, 107 819-863.

Davis, Steven J., John Haltiwanger and Scott Schuh (1996) Job Creation and Destruction, Cambridge, Massachusetts: MIT Press.

Dunne, Timothy, Mark J. Roberts and Larry Samuelson (1989) "The Growth and Failure of U.S. Manufacturing Plants," Quarterly Journal of Economics, 104, 671-698.

Dunne, Timothy and James Schmitz (1991) "Technology and Wages at U.S. Manufacturing Plants," mimeo, Center for Economic Studies, August.

Ericson, Richard and Ariel Pakes (1990) "'An Alternative Theory of Firm and Industry Dynamics," working paper, Yale University.

Farber, Henry S. and Daniel H. Saks (1980) "Why Workers Want Unions: The Role of Relative Wages and Job Characteristics," Journal of Political Economy, 88, no. 2 (April), 349-369. 
Freeman, Richard (1980) "Unionism and the Dispersion of Wages," Industrial and Labor Relations Review, 34, 3-23.

Freeman, Richard (1982) "Union Wage Practices and Wage Dispersion Within Establishments," Industrial and Labor Relations Review, 36, 3-21.

Freeman, Richard and James Medoff (1984) What Do Unions Do? New York: Basic Books.

Garen, John (1985) "Worker Heterogeneity, Job Screening, and Firm Size," Journal of Political Economy, 93, 715-739.

Hamermesh, Daniel S. (1980) "Commentary," in The Economics of Firm Size, Market Structure, and Social Performance, edited by John J. Siegfried, Washington: Federal Trade Commission.

Hirsch, Barry T. and John T. Addison (1986) The Economic Analysis of Unions, Allen and Unwin: Boston, Massachusetts.

Jovanovic, Boyan (1982) "Selection and the Evolution of Industry," Econometrica, 50, 3, 649-670.

Juhn, Chinhui, Kevin M. Murphy and Brooks Pierce (1993) "Wage Inequality and the Rise in Returns to Skill," Journal of Political Economy, 101, no. 3, 410-442.

Kahn, Lawrence and Michael Curme (1987) "Unions and Nonunion Wage Dispersion," Review of Economics and Statistics, 69, 600-607.

Katz, Lawrence F. and Kevin M. Murphy (1992) "Changes in Relative Wages, 1963-87: Supply and Demand Factors," forthcoming in the Quarterly Journal of Economics.

Katz, Lawrence F. and Lawrence H. Summers (1989) "Industry Rents: Evidence and Implications," Brookings Papers on Economic Activity, Microeconomics, 209-275.

Lambson, Val E. (1991) "Industry Evolution with Sunk Costs and Uncertain Market Conditions," International Journal of Industrial Organization, 9, no. 2, 171-196. 
Lazear, Edward and Sherwin Rosen (1981) "Rank-Order Tournaments as Optimum Labor Contracts," Journal of Political Economy, 89, 841-864.

Lazear, Edward (1989) "Pay Equality and Industrial Politics," Journal of Political Economy, 97, 561-580.

Lester, Richard (1967) "Pay Differentials by Size of Establishment," Industrial Relations, 7, (October).

Lewis, H. Gregg (1986) Union Relative Wage Effects: A Survey, Chicago: The University of Chicago Press.

Lucas, Robert E. (1977) "On the Size Distribution of Business Firms," Bell Journal of Economics, 9, 508-523.

Mellow, Wesley (1982) "Employer Size and Wages," Review of Economics and Statistics, 64, (August), 495-501.

Moore, H.L. (1911) Laws of Wages: An Essay in Statistical Economics, New York: Augustus M. Kelley.

Oi, Walter (1983) "The Fixed Costs of Specialized Labor," in Jack Triplett, ed., The Measurement of Labor Cost, Chicago: University of Chicago Press.

Podgursky, Michael (1986) "Unions, Establishment Size, and Intra-Industry Threat Effects," Industrial and Labor Relations Review, 39, no. 2, 277-284.

Rehn, Gösta (1954) "Unionism and the Wage Structure," International Economic Association Conference on Wage Determination.

Reynolds, Lloyd G. and Cynthia H. Taft (1956) The Evolution of Wage Structure, New Haven, Connecticut: Yale University Press.

Rosen, Sherwin (1986) "The Theory of Equalizing Differences," in O. Ashenfelter and R. Layard, eds., Handbook of Labor Economics, volume I, Amsterdam: North-Holland. 
Troske, Kenneth R. (1994) "Evidence on the Employer Size-Wage Premium from WorkerEstablishment Matched Data," U.S. Bureau of the Census, Center for Economic Studies Discussion Paper 94-10.

Voos, Paula (1983) "Union Organizing: Costs and Benefits," Industrial and Labor Relations Review, 36 , no. 4 (July). 
FIGURE 1

HOURLY WAGES BY PLANT SIZE CLASS

PRODUCTION WORKERS, 1982

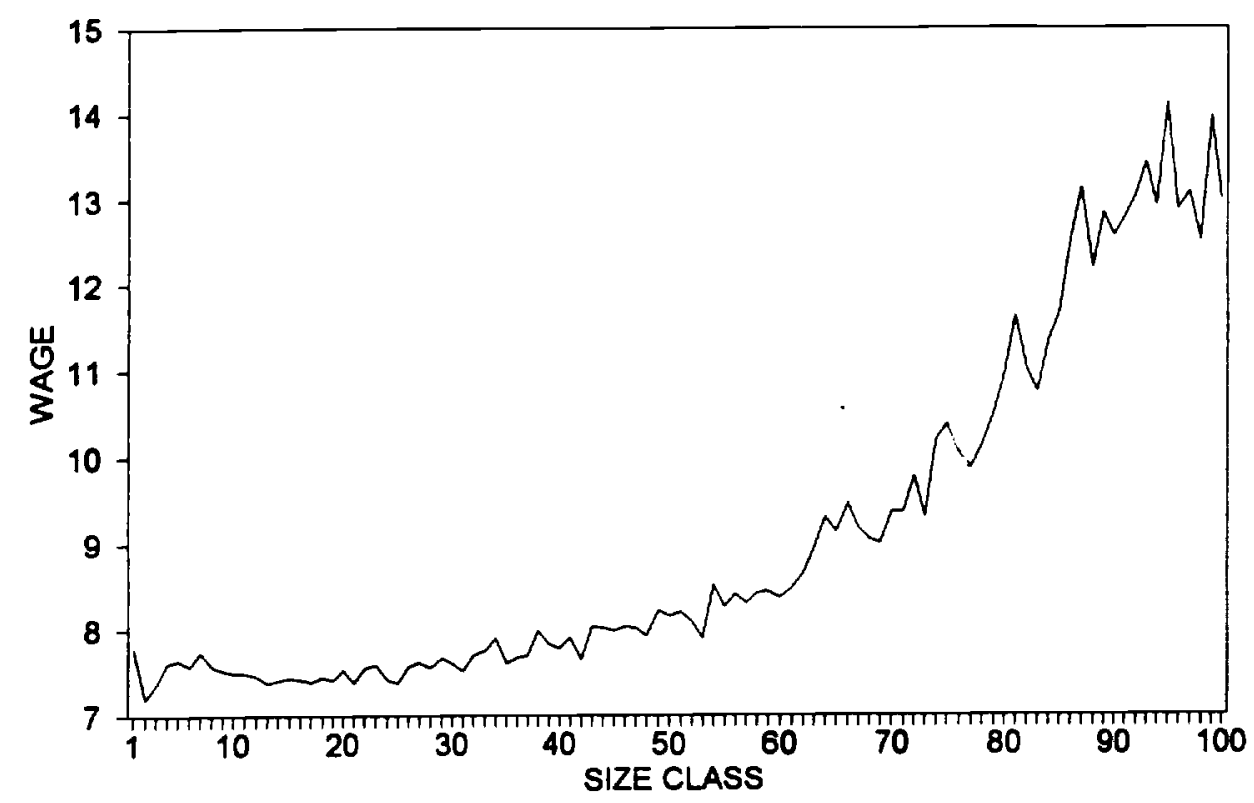

FIGURE 2

HOURLY WAGES BY PLANT SIZE CLASS

NONPRODUCTION WORKERS, 1982

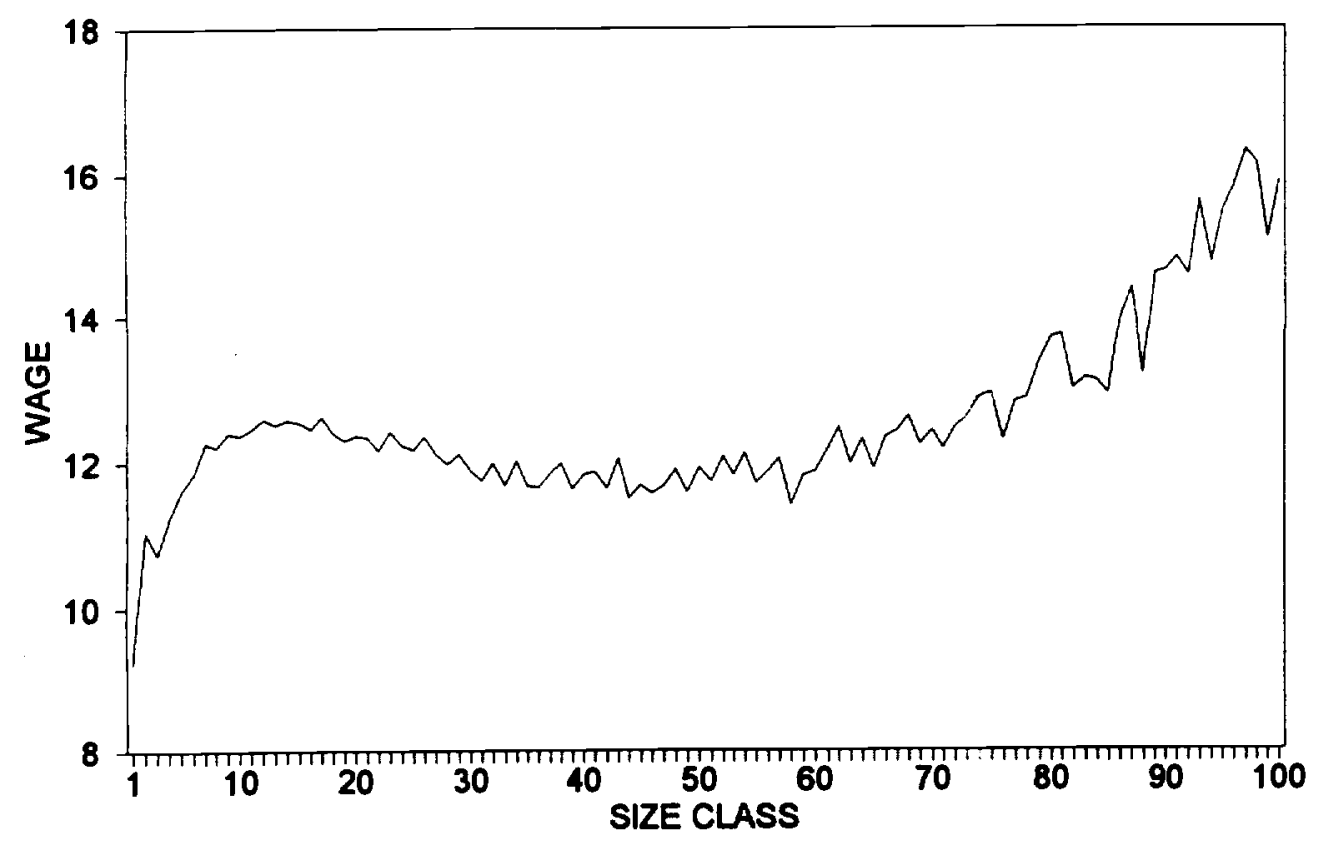


FIGURE 3

MEAN WAGES AND WAGE DISPERSION BY PLANT SIZE (PROD WORKERS)

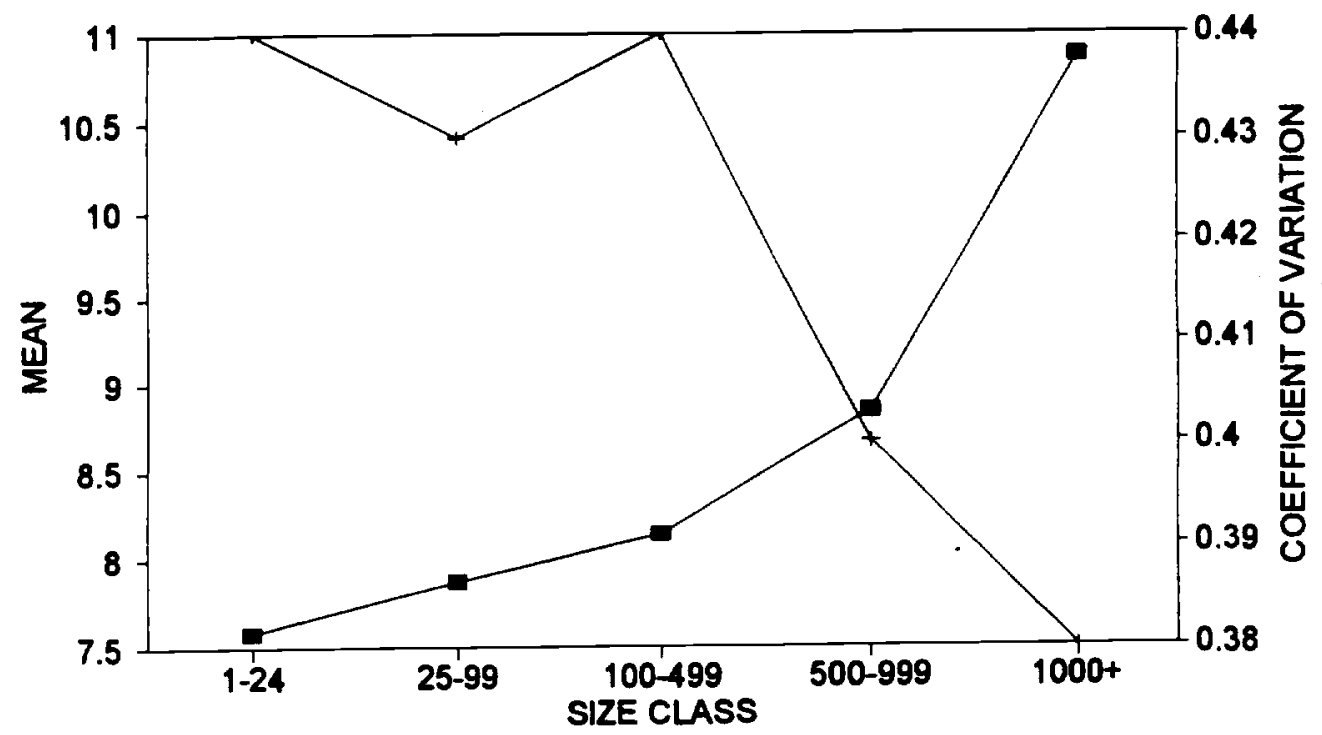

- MEAN $\quad$ COEFF OF VAR

FIGURE 4

MEAN WAGES AND WAGE DISPERSION BY PLANT SIZE(NONPROD WORKERS)

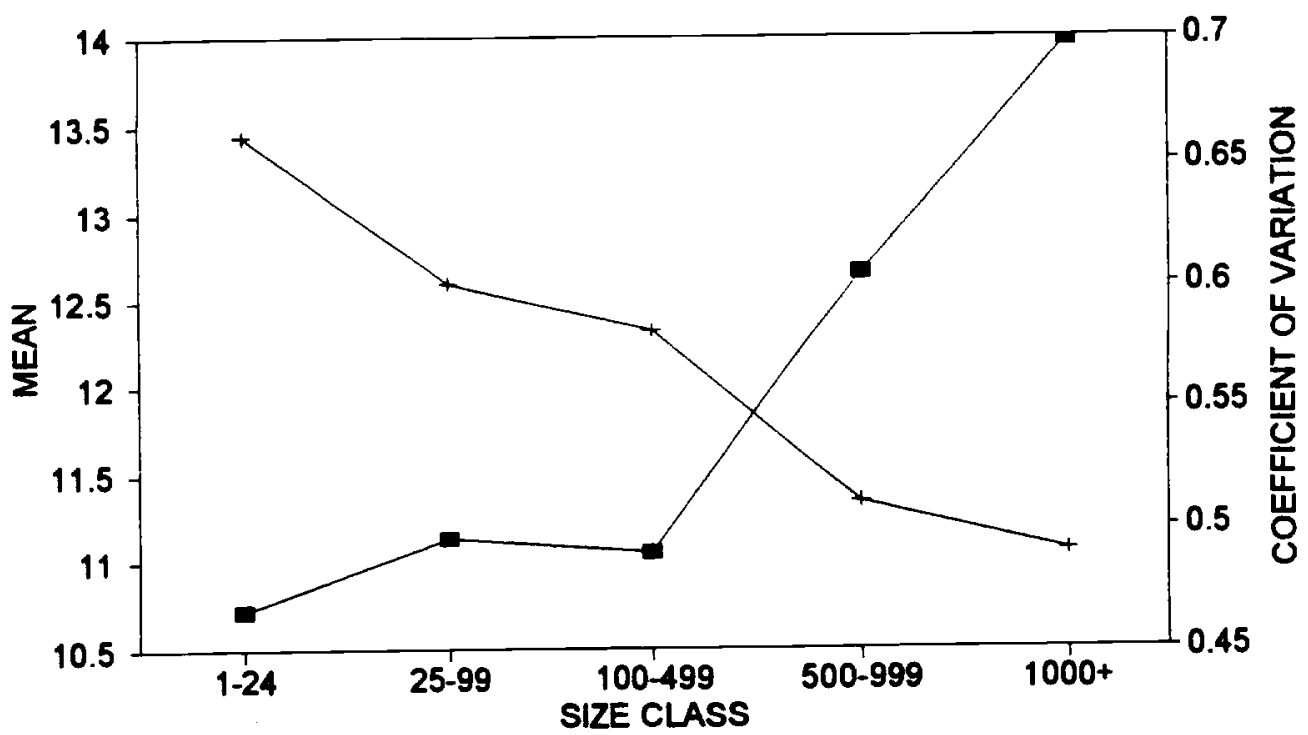

$\rightarrow$ MEAN + COEFF OF VAR 


\section{FIGURE 5}

ACTUAL AND PREDICTED SIZE WAGE

DIFFERENTIALS (PROD WORKERS)

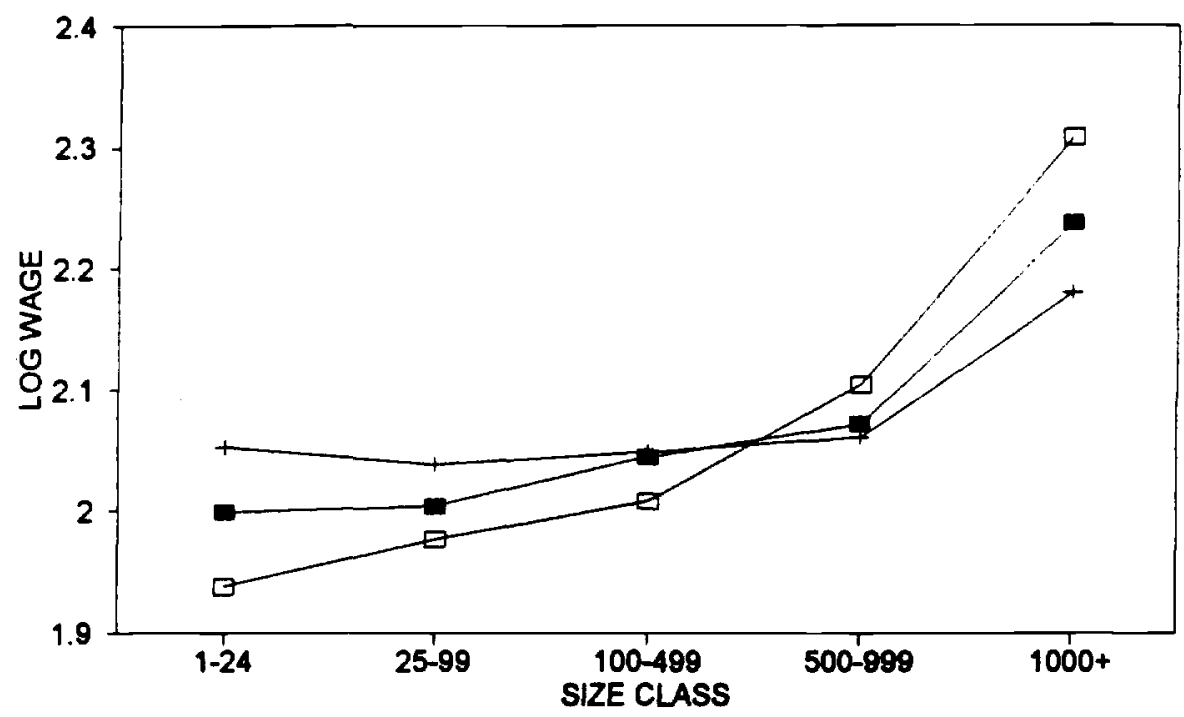

PRED-ALL CONTROLS $\longrightarrow$ PRED-HUMAN CAPTTAL $\square$ ACTUAL

ACTUAL AND PREDICTED SIZE WAGE

DIFFERENTIALS (NONPROD WORKERS)

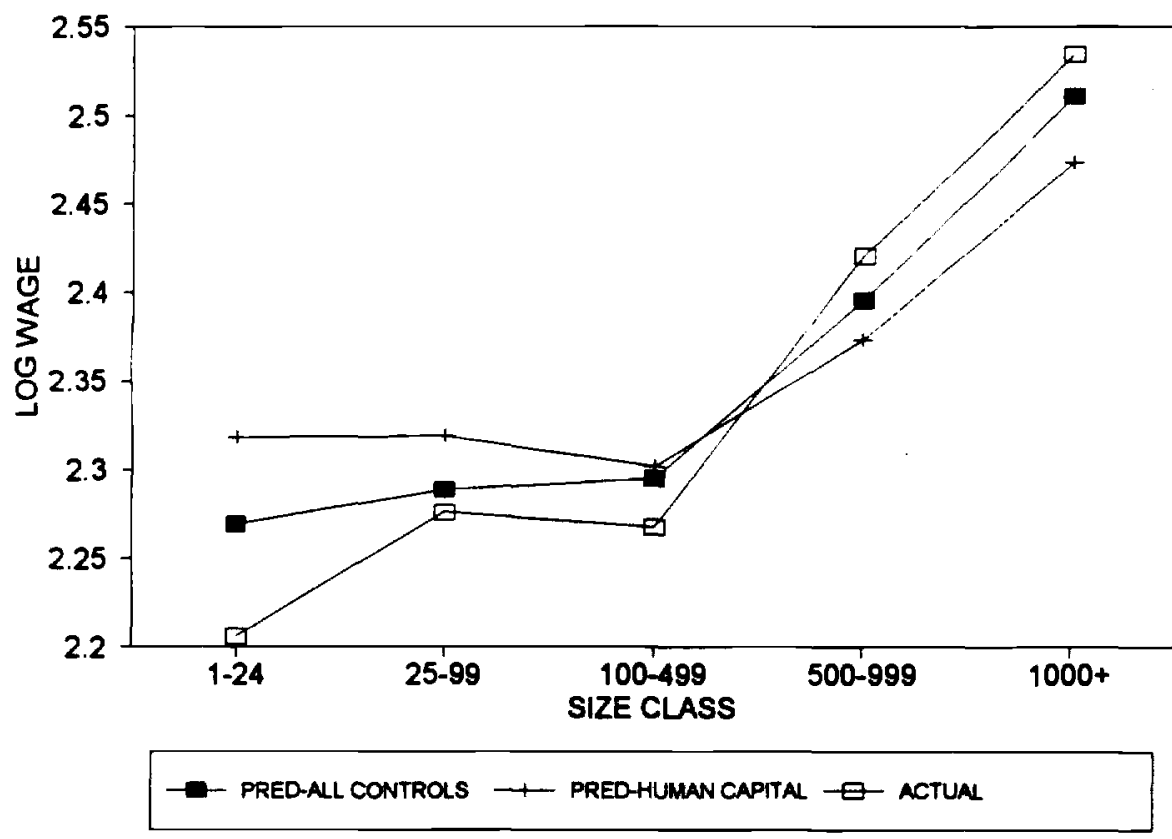




\section{FIGURE 6}

DECOMPOSITION OF WAGE DISPERSION BY SIZE CLASS (PRODUCTION WORKERS)

A. ACTUAL 90-10 DIFFERENTIAL

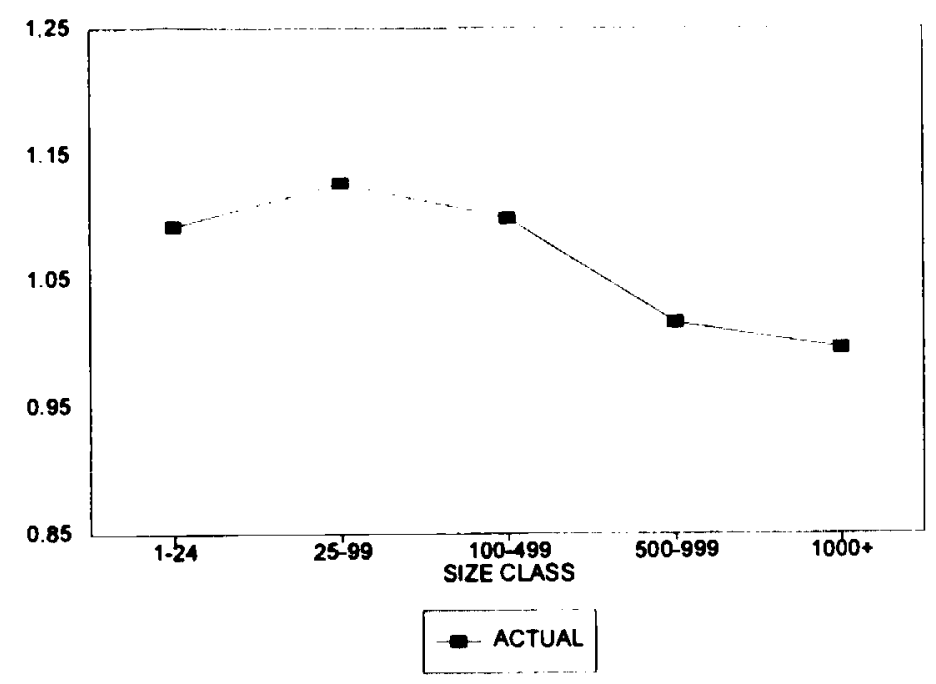

C. OBSERVABLE WAGES

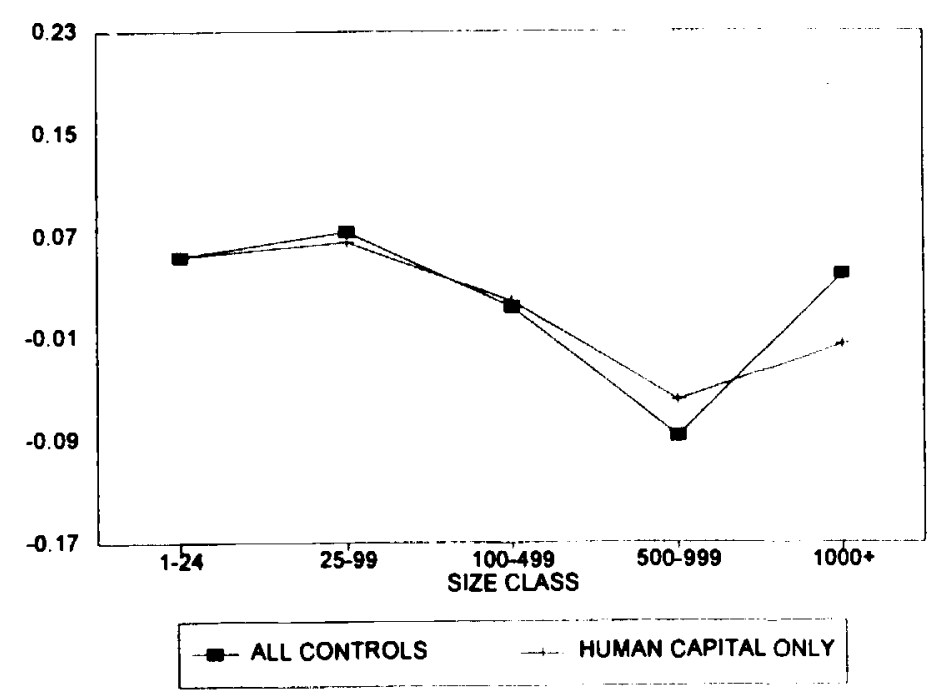

B. OBSERVABLE CHARACTERISTICS

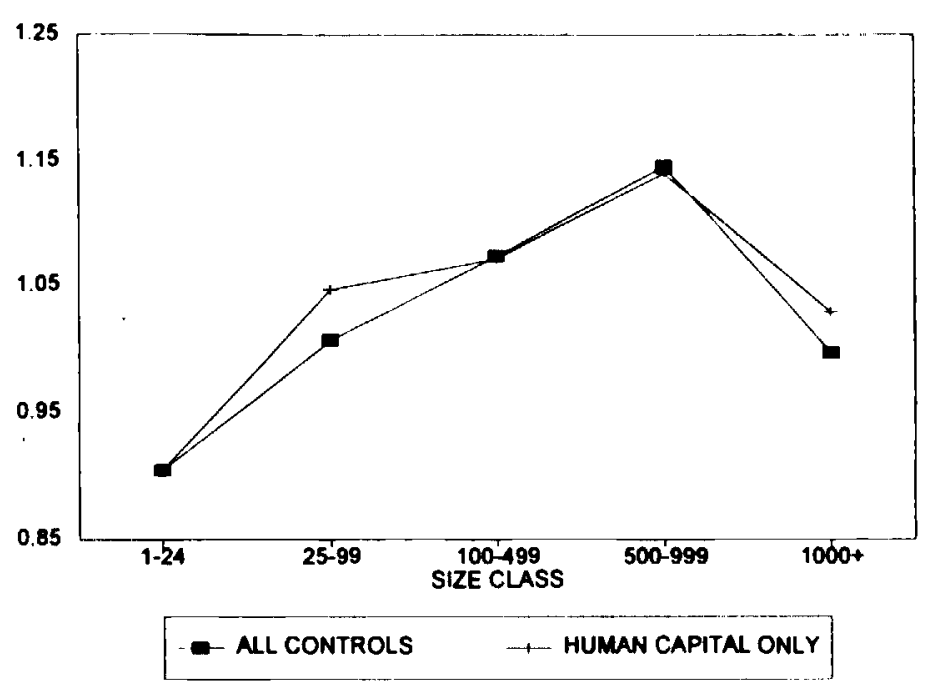

D. UNOBSERVABLES

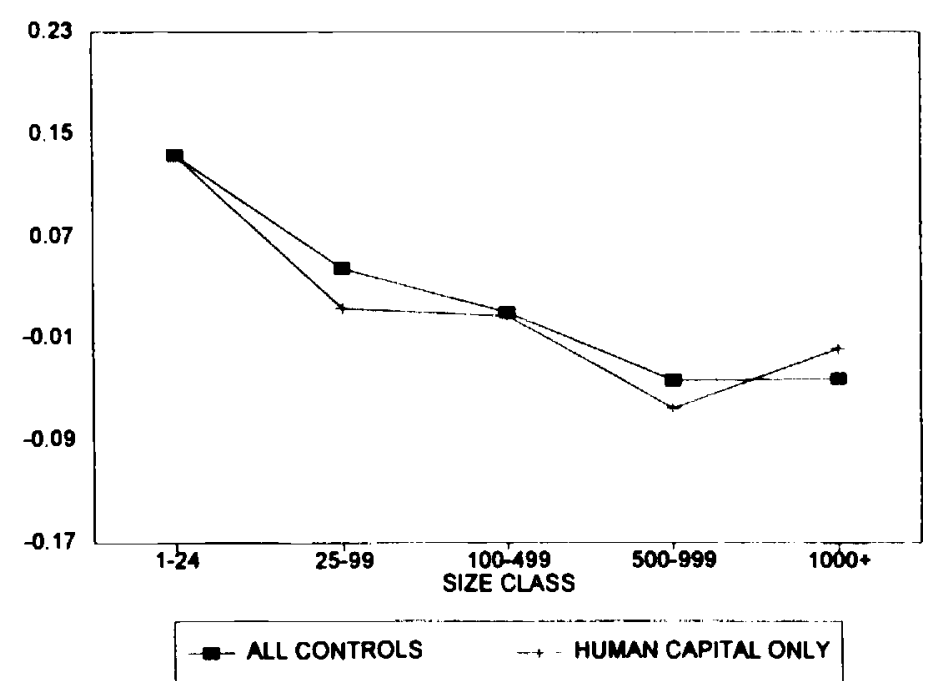


FIGURE 7

DECOMPOSITION OF WAGE DISPERSION BY SIZE CLASS (NONPRODUCTION WORKERS)

A. ACTUAL 90-10 DIFFERENTIAL

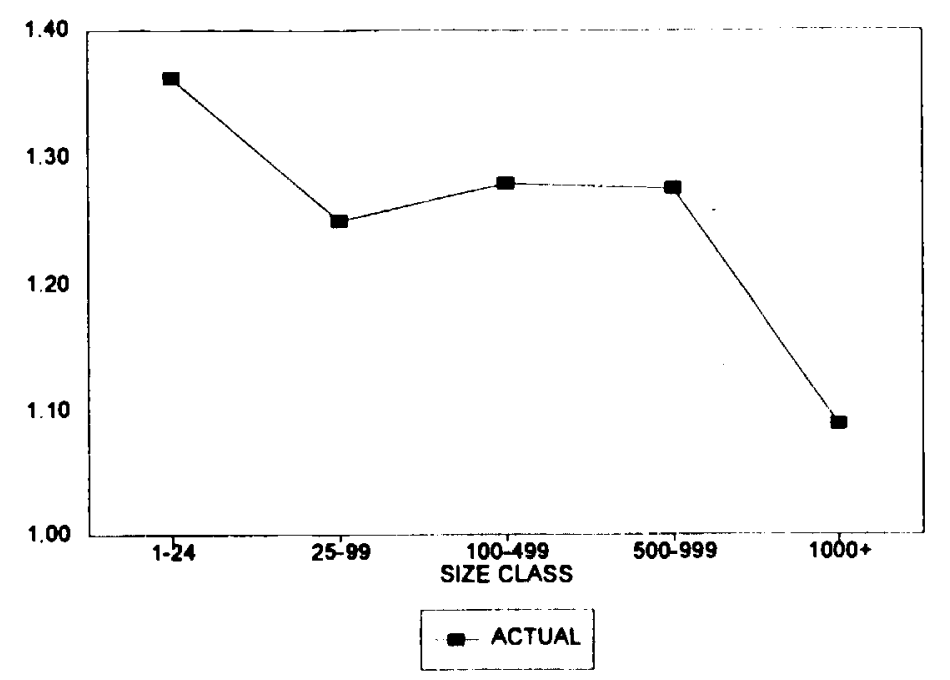

C. OBSERVABLE WAGES

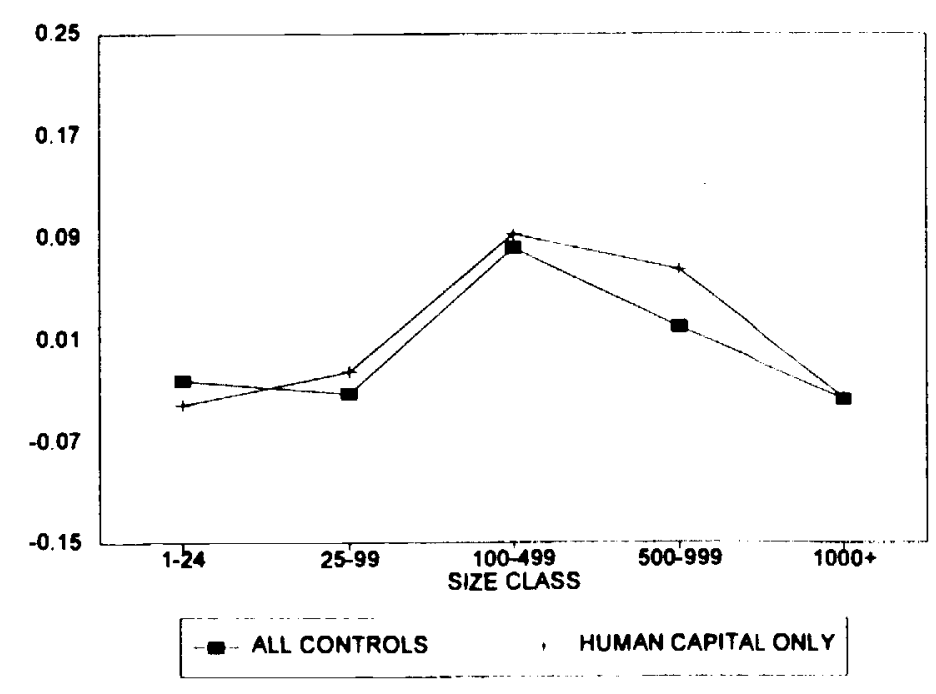

B. OBSERVABLE CHARACTERISTICS
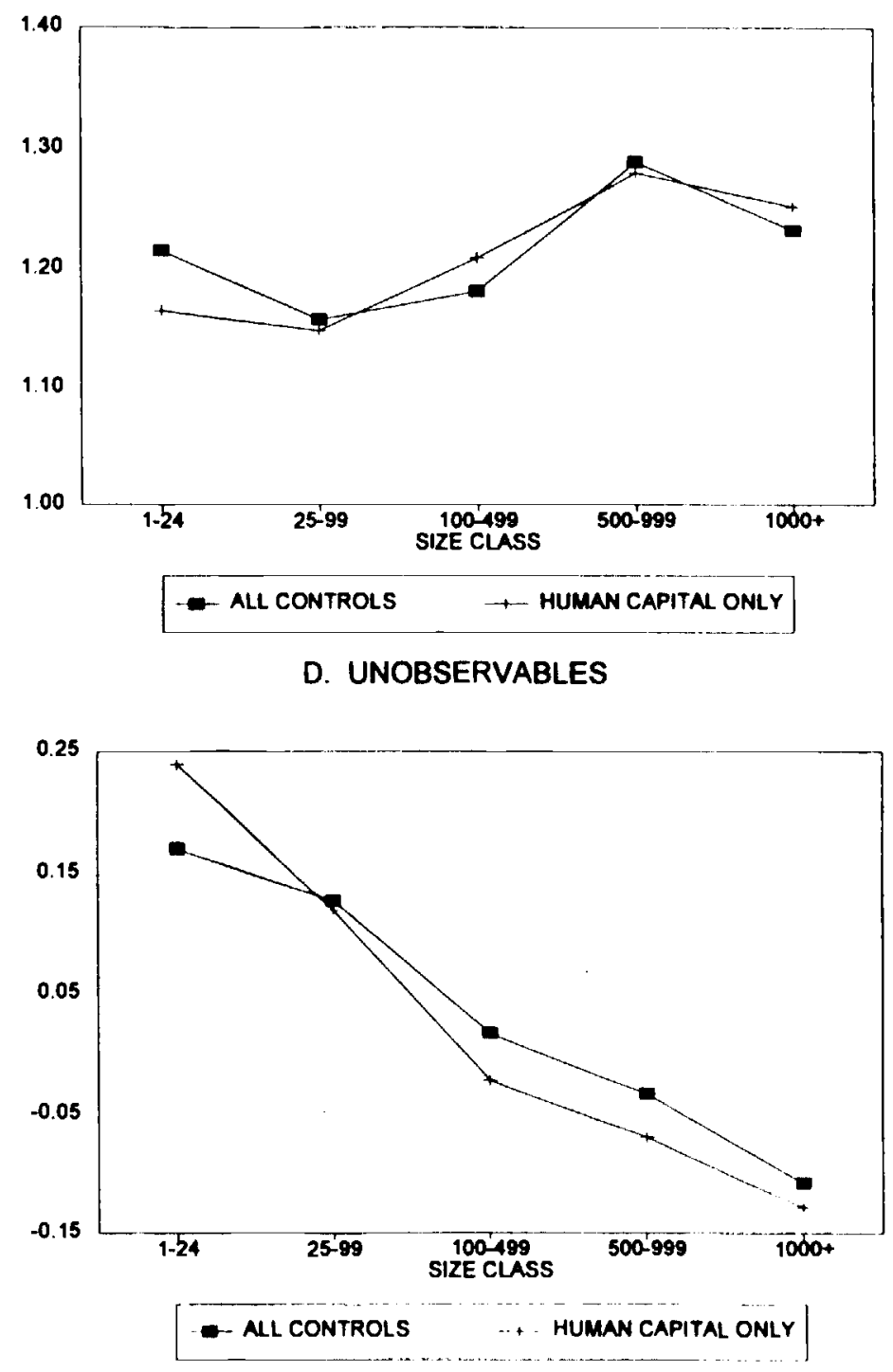
FIGURE 8

DECOMPOSITION OF WAGE DISPERSION BY SIZE CLASS (PRODUCTION WORKERS)

A. ACTUAL 90-50 DIFFERENTIAL

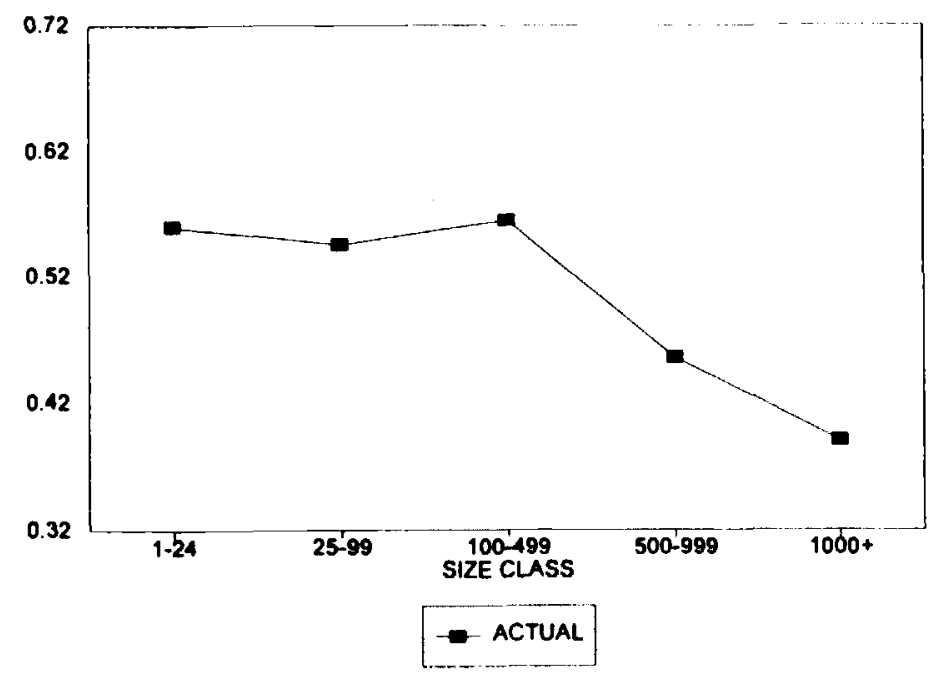

C. OBSERVABLE WAGES

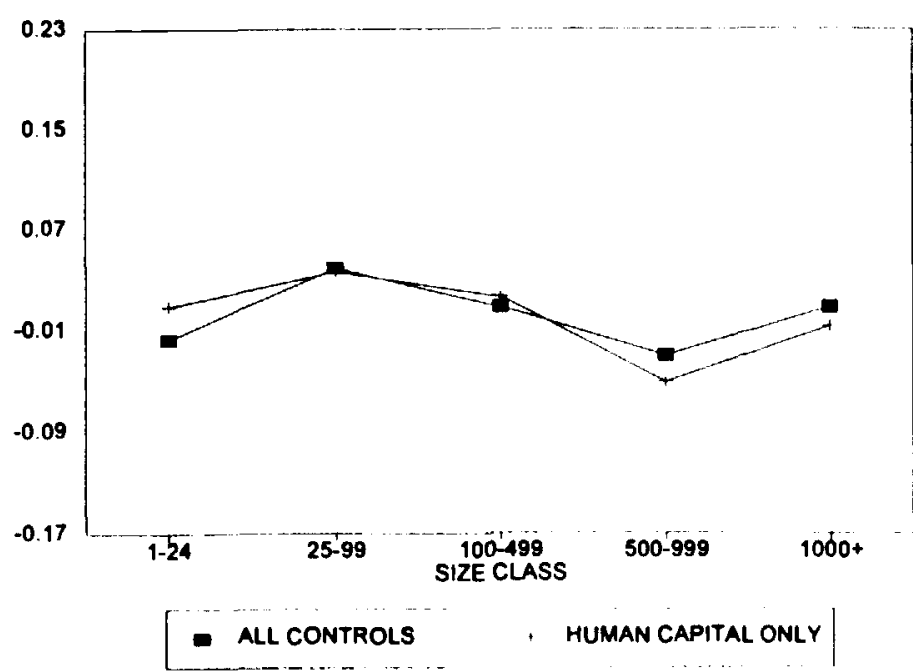

B. OBSERVABLE CHARACTERISTICS

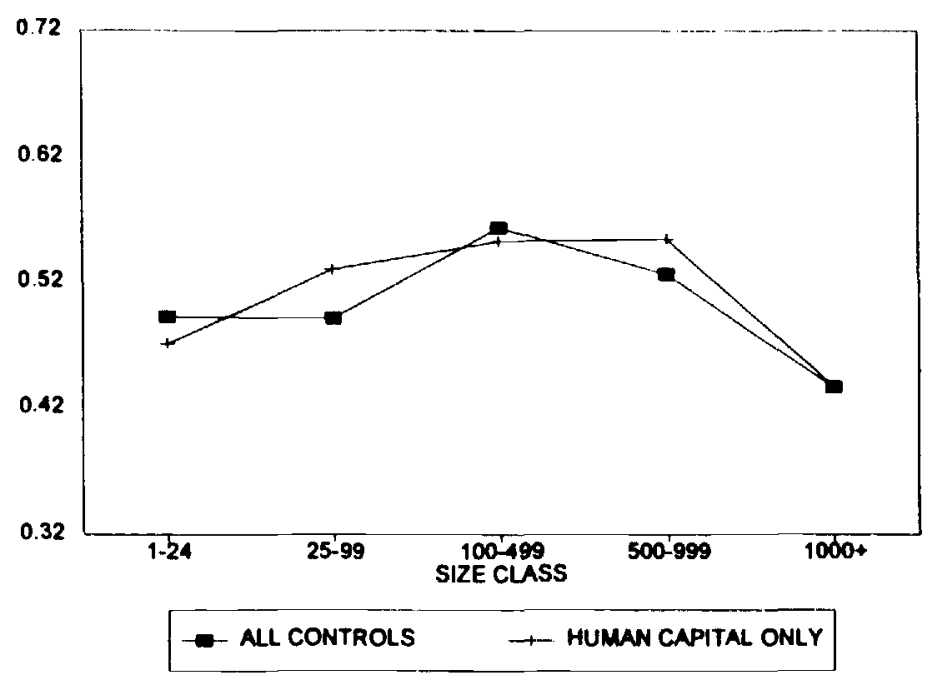

D. UNOBSERVABLES

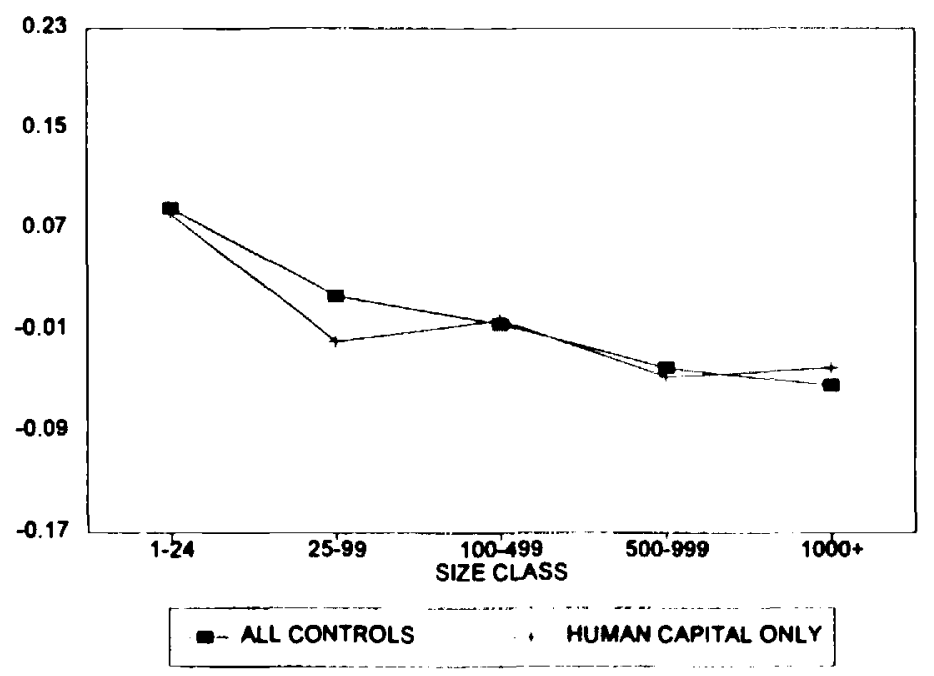




\section{FIGURE 9}

DECOMPOSITION OF WAGE DISPERSION BY SIZE CLASS (NONPRODUCTION WORKERS)

A. ACTUAL 90-50 DIFFERENTIAL

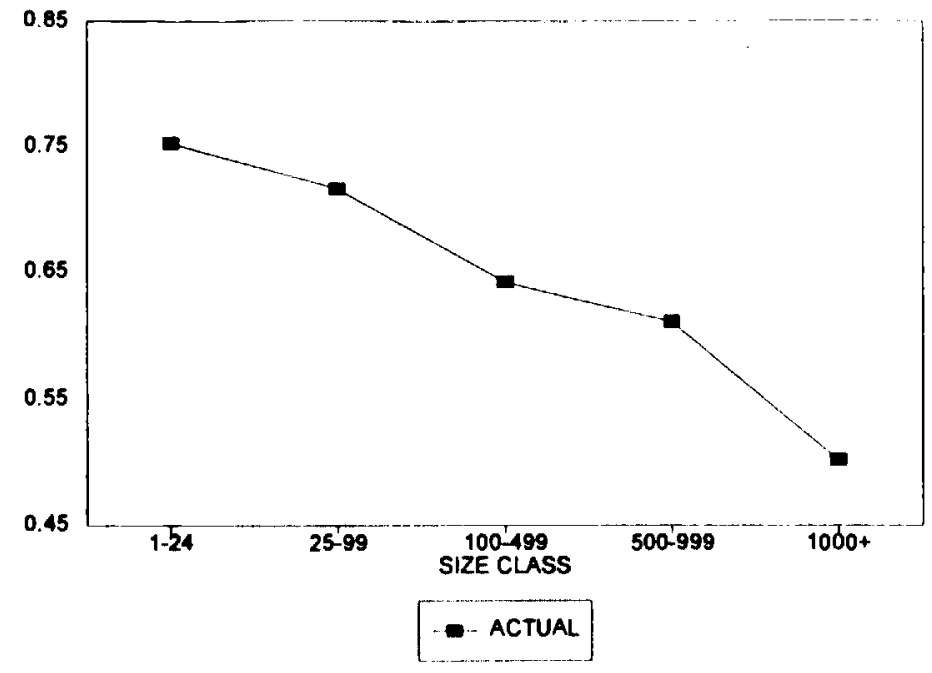

C. OBSERVABLE WAGES

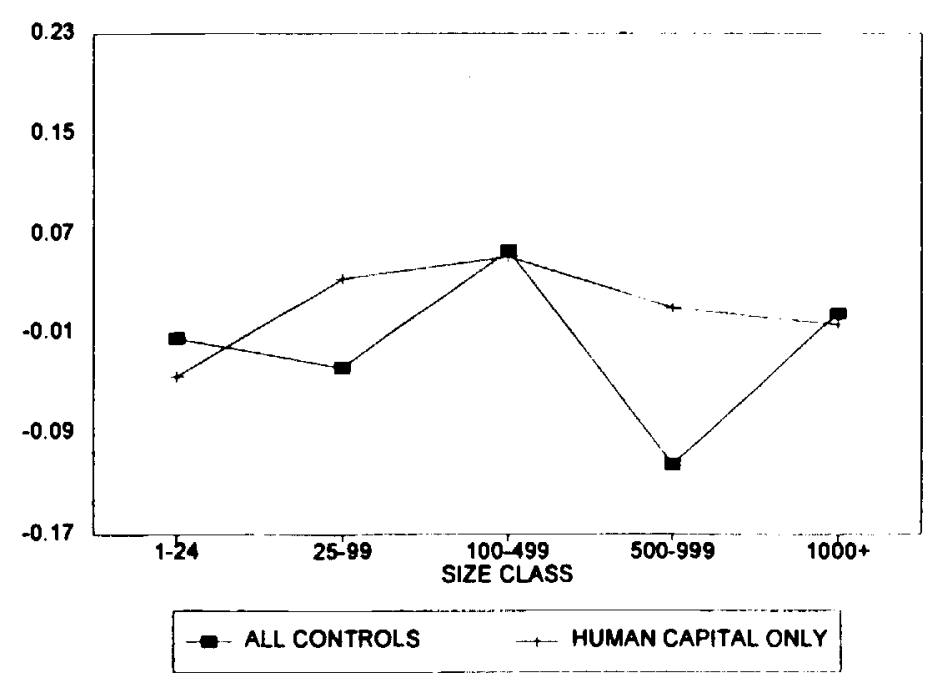

B. OBSERVABLE CHARACTERISTICS
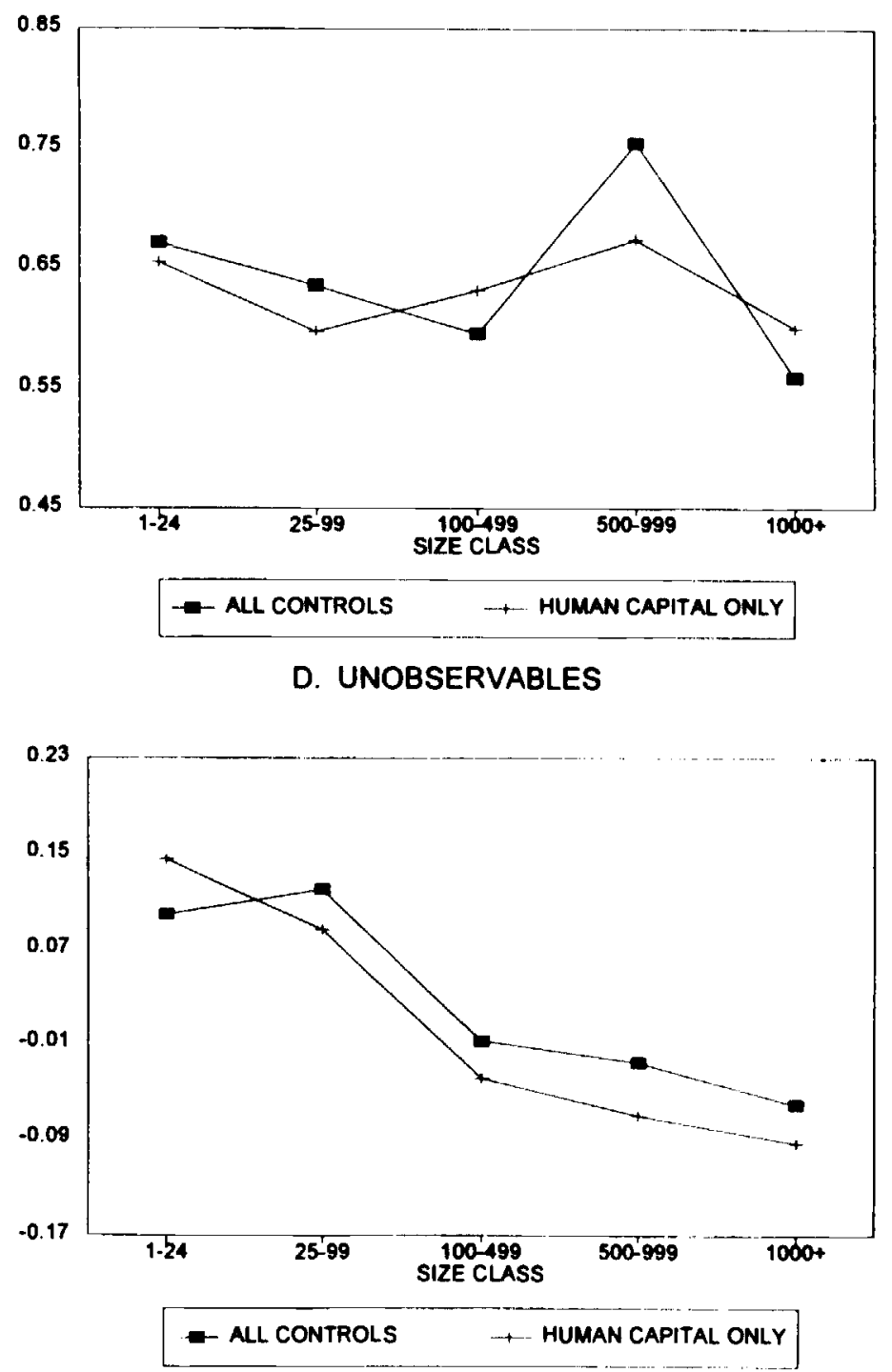
FIGURE 10

DECOMPOSITION OF WAGE DISPERSION BY SIZE CLASS (PRODUCTION WORKERS)

A. ACTUAL 50-10 DIFFERENTIAL

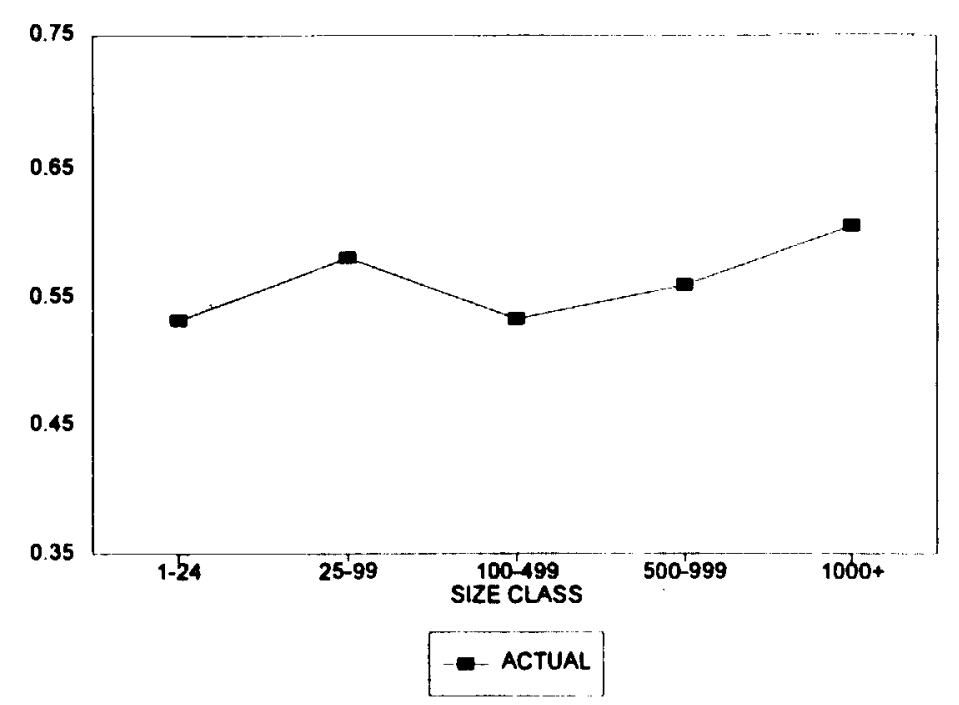

C. OBSERVABLE WAGES

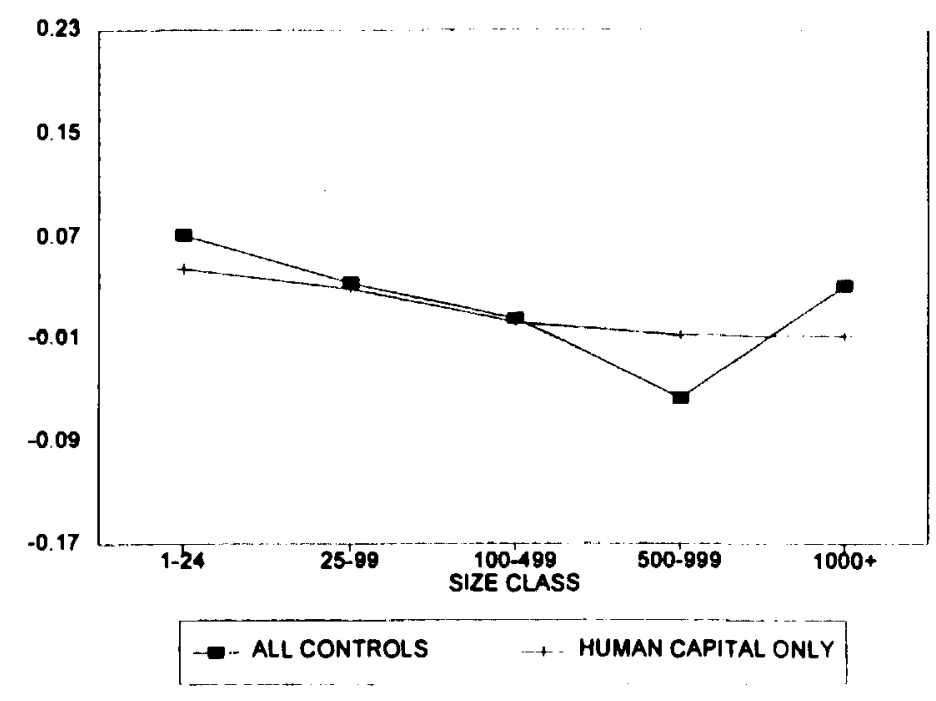

B. OBSERVABLE CHARACTERISTICS

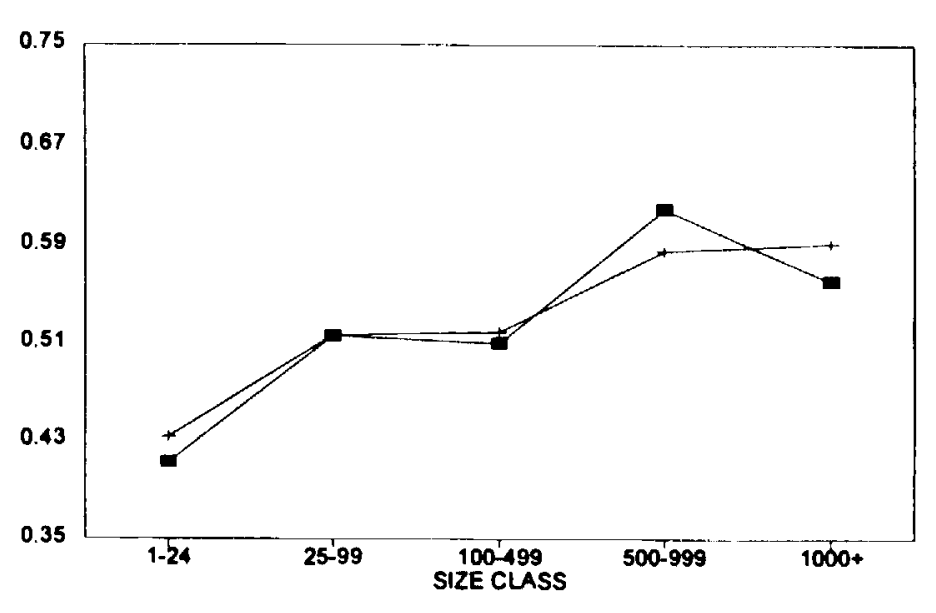

- all controls t human capital only

D. UNOBSERVABLES

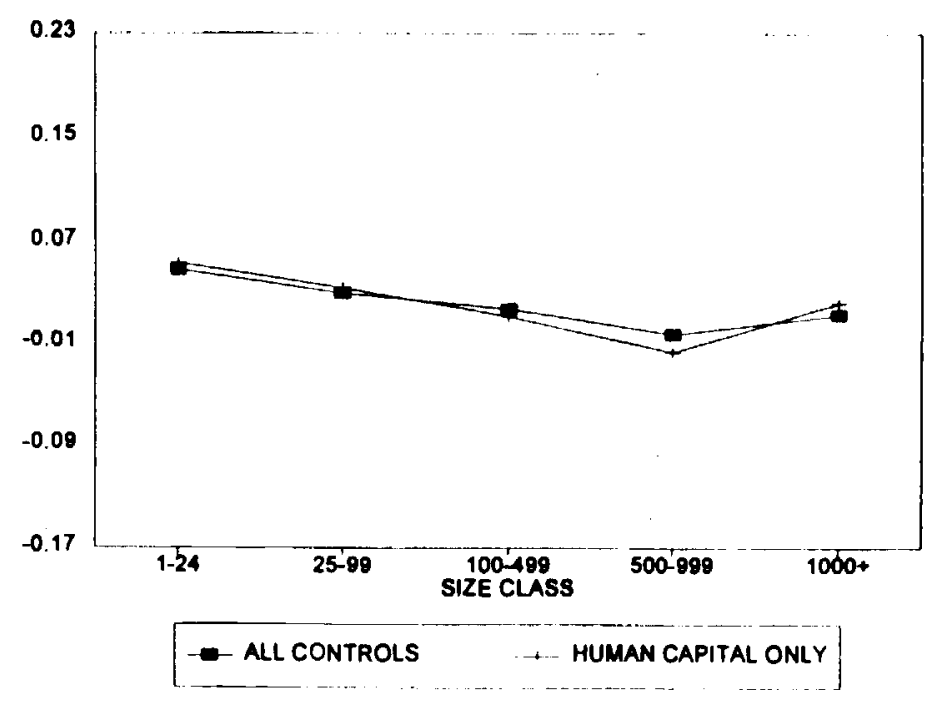


DECOMPOSITION OF WAGE DISPERSION BY SIZE CLASS (NONPRODUCTION WORKERS)

A. ACTUAL 50-10 DIFFERENTIAL

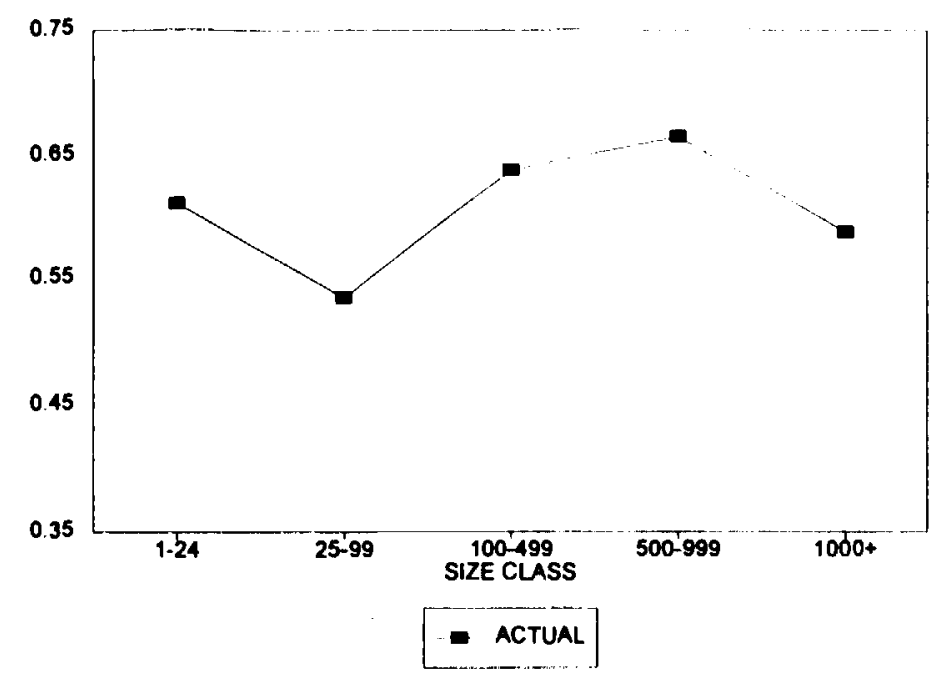

C. OBSERVABLE WAGES

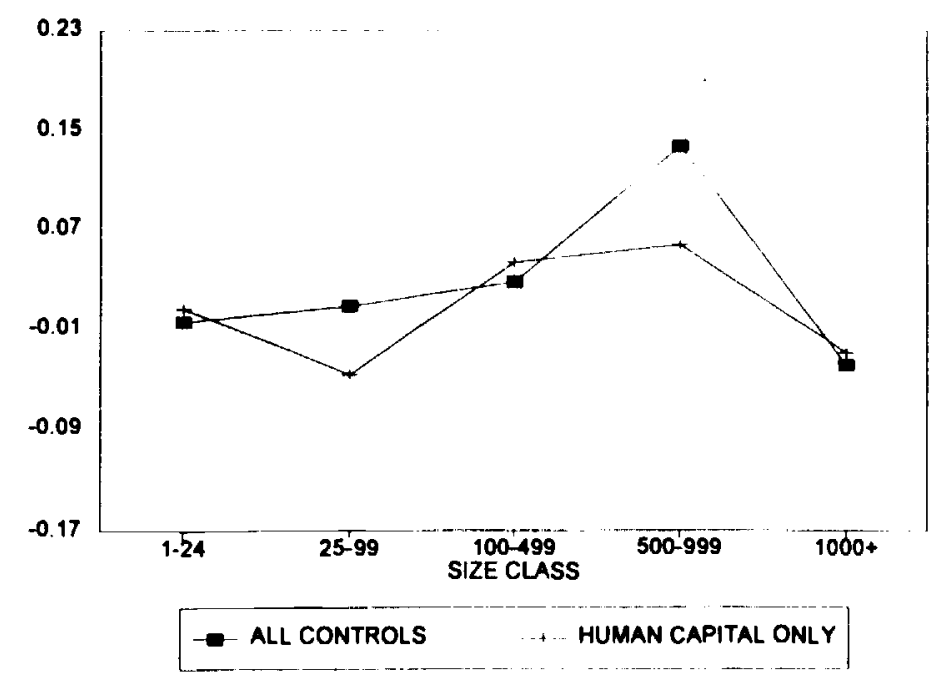

B. OBSERVABLE CHARACTERISTICS

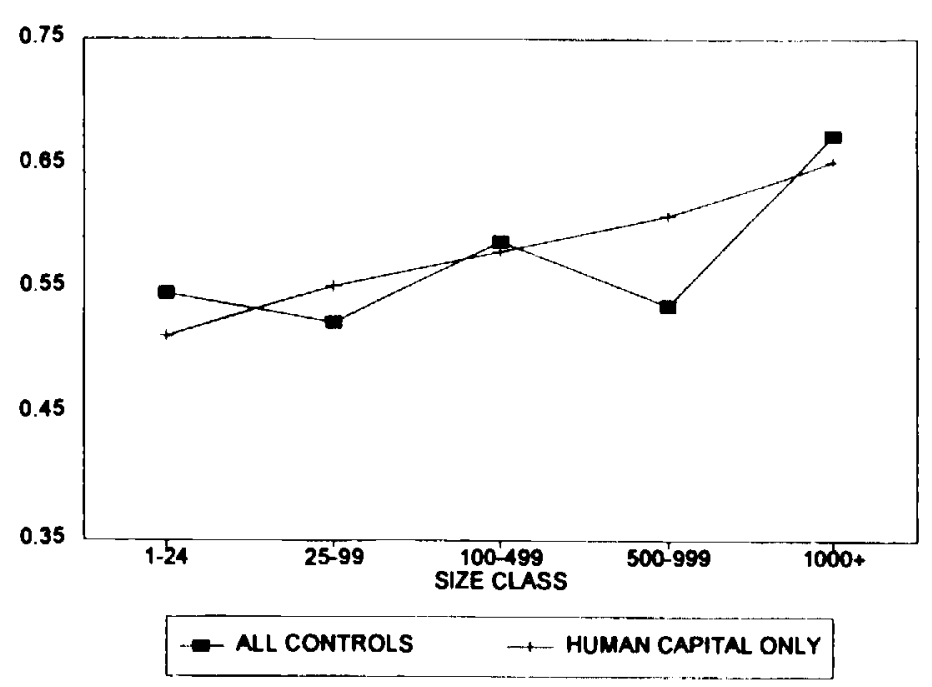

D. UNOBSERVABLES

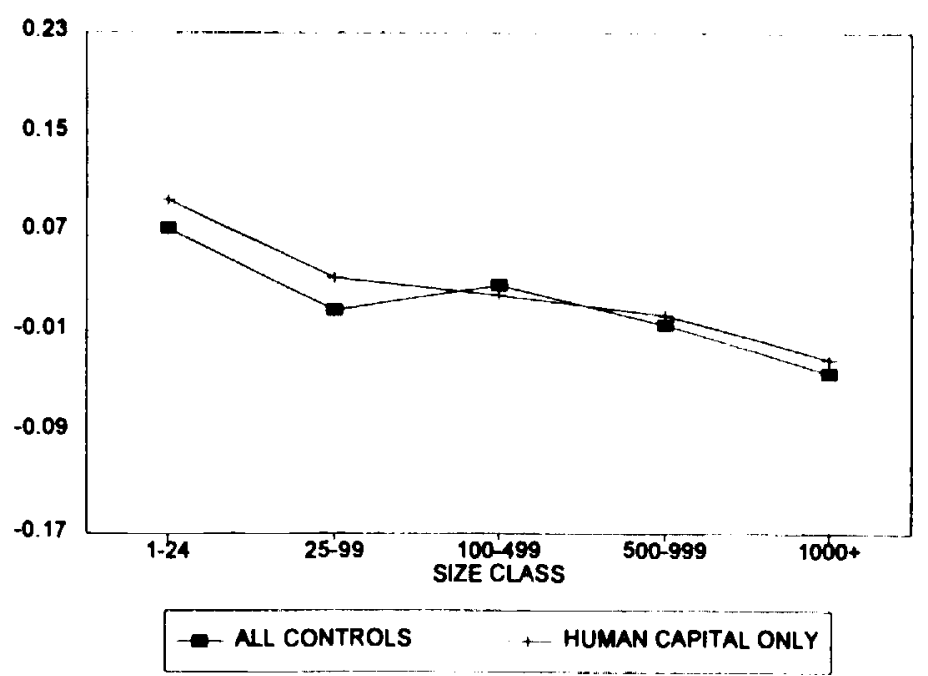




\section{FIGURE 12 COEFFICIENT OF VARIATION BY PLANT SIZE}

WITHIN PLANT, BETWEEN PLANT

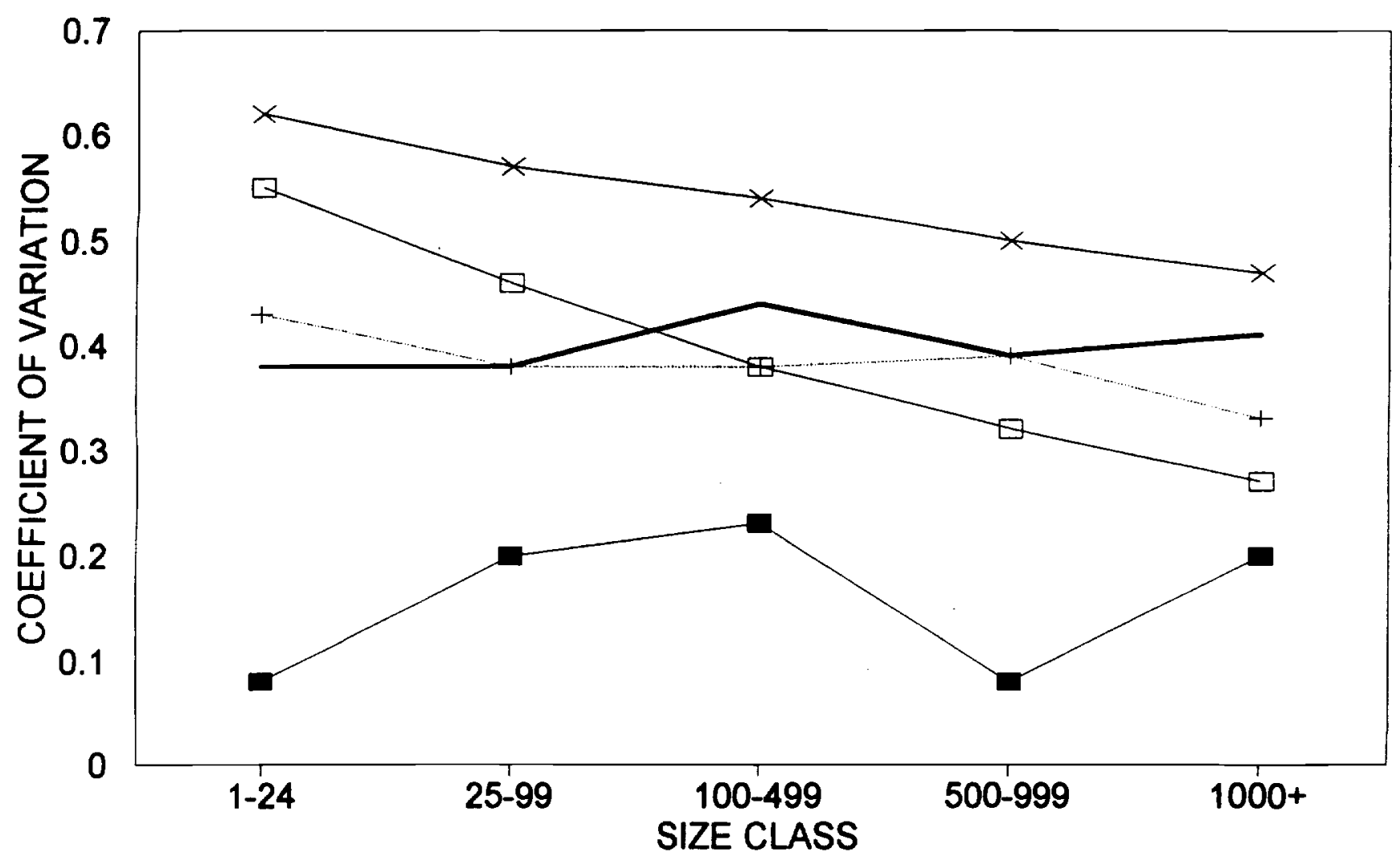

